\title{
Iconografía y clasificación de las armas hititas
}

\author{
FÉlix Alonso y Royano *
}

\begin{abstract}
Dedicatoria: A todos aquellos, aficionados, estudiantes, profesores, que de manera anodina laboran la piedra filosolal del conocimiento que hace avanzar culturalmente al humano y alejarse de la brutal y oscura violencia. Esperemos que, armas y batallas sean, algún dia, sólo historia a recordar.

Y a mis hijos José Félix, Laura, Javier y Eduardo para que sepan caminar en el futuro inmediato con la paz en la mano.

En Bitbao, tierra quemada por la violencia (terrorista, política y callejera), a 15 de junio del año 2000, en el setecientos aniversario de su carta de población, otorgando el Fuero de Logroño el Señor D. Diego López de Haro.
\end{abstract}

\section{RESUMEN ABSTRACT}

Se trata de un trabajo de aproximación sobre el armamento hitita ( $y$, por supuesto, de los reinos relacionados de alguna manera con Hatti), y de la relación

historia de los pueblos que convivieron con ellos $y$, por otro lado, de una materia no tratada en nuestro país, hasta el momento.

El Dr. Alonso y Royano es persona preocupada por toda la cuestión sociopolítica de la antigüedad, preponderántemente sobre cuestiones juridicas. De suerte que, si bien es cierto que la especialidad armamentística no

entra en su especialización, ésta si conforma un aspecto sociopolítico y, en ese sentido, también jurídico que es el
This work is an approach on the subject of the armament of Hitita (it also deals with the Kingdoms that were somehow related with Hatti), the historic relation of the towns were close to, and influenced by Hatti. It deals with the subject utilising material never before used in this country.

Dr. Alonso y Royano is mainly interested in the socio-politico aspect of the ancient times, predominately in the juridical field. It is fortunate that if the field of armoury does not enter into his area of specialisation, this conforms to his socio-politico interests, this combined the judicial

* Doctor en Derecho. Egiptólogo de la Fondation Egyptologique Reine Elisabeth. Bruxelles. Profesor Tutor de la UNED. CAB Centro Asociado “Bizkaia». 
que, en el fondo, él siempre trata. Los hititólogos han tratado la historia de

Hatti desde multitud de ángulos, pero nunca desde el aspecto armamentístico.

Cuestión, por otro lado, junto a la diplomacia, que hace que un imperio se mantenga más o menos tiempo en el "tiempo histórico".

De modo que este trabajo de "acercamiento" a la iconografía armamentistica hitita no es otra cosa que una "invitación" a los especialistas, si es que los hay, para que nos ilustren sobre el tema. the judicial angle is, how he deals with the topic.

The hitilologists have dealt with the history form many different angles, but never from the armamentarium aspect, this coupled with diplomacy is what causes an Empire to maintain itself more or less in ancient times. This work on the lconography of the armoury of Hatti could be conceived as more of an invitation to specialists of this subject (if, indeed such a thing exists) to help illustrate the subject further.

\section{Índice}

1. Cronología Hitita.

2. Clasificación armamental esquemática.

3. Una aproximación a la historia hitita.

4. Lengua y escritura.

5. Textos históricos.

6. El ejército.

6.1. Arquitectura militar (fortalezas, murallas, torres, arietes, móviles de asaito).

6.2. Armas ofensivas y defensivas.

6.2.1. Ofensivas.

6.2.1.1. Espadas.

6.2.1.2. Hachas.

6.2.1.3. Bidentes.

6.2.1.4. Mazas.

6.2.1.5. Venablos.

6.2.1.6. Arcos y flechas.

6.2.1.7. Calderos.

6.2.2. Defensivas.

6.2.2.1. Cascos

6.2.2.2. Armaduras.

6.2.2.2.1. Petos.

6.2.2.2.2. Cotas de malla.

6.2.2.2.3. Placas o planchas.

6.2.2.3. Escudos.

7. La Infantería. 
8. La Caballería.

8.1. Carros ligeros o de combate.

8.2. Carros pesados o de transporte e intendencia.

9. La Marina.

9.1. Barcos.

10. Conclusiones.

11. Bibliografía no exhaustiva.

12. Abreviaturas utilizadas en la bibliografía.

1. CRONOLOGIA HITITA **

$\begin{array}{ll}\text { Época Protohitita } & 2000 / 1700 \text { a.C. } \\ \text { Antiguo Reino } & 1750 / 1500 \\ \text { Periodo oscuro } & 1500 / 1450 \\ \text { Imperio Nuevo } & 1450 / 1336 \\ \text { Shubiluliuma } & 1380 / 1336 \\ \text { Segundo Imperio } & 1336 / 1215 \\ \text { Destrucción por los Frigios } & \\ \quad \text { y Gasgas } & 1200 / 1150\end{array}$

Reyes

Primer Imperio o antiguo.

$\begin{array}{lc}\text { Pithana } & 1850 / 1800 \text { a.C. aprox. } \\ \text { Anitta } & 1800 i \\ \text { Peruwa } & i \text { “ } \\ \text { Tudhaliya I } & 1740 / 1710 \\ \text { Pusarruma } & 1710 / 1680 \\ \text { Tlabarna I } & i ? \\ \text { Hattusil I } & 1650 / ? \\ \text { Tlabarna II } & 1650 / 1620 \\ \text { Mursil I } & 1620 / 1590 \\ \text { Hantil I } & 1590 / 1560 \\ \text { Zidanta I } & 1560 / 1550 \\ \text { Ammuna } & 1550 / 1530 \\ \text { Huziya I } & 1530 / 1525 \\ \text { Telepinu } & 1525 / 1500\end{array}$

\section{Crisis Imperial}

$\begin{array}{lll}\text { Alluwanna } & 1500 / 1490 & \\ \text { Hantil II } & 1490 / 1480 & 1475 \\ \text { Zidanta II } & 1480 / 1470 & 1460 \\ \text { Huziya II } & 1470 / 1460 & 1440\end{array}$

** Según Fernández URIEl, $P$

*** Según Martin-Brugeras, M. ${ }^{a} \mathbf{M}$.

**** Según OTTEN, H 


$\begin{array}{lll}\text { Tudhaliya II } & 1460 / 1440 & \\ \text { Arnuwanda I } & 1440 / 1420 & 1400 \\ \text { Hattusil II } & 1420 / 1400 & \\ \text { Tudhaliya III } & 1400 / 1385 / 75 & \\ \text { Arnuwanda II } & 1385 / 1380 & \end{array}$

\section{Gran Imperio o Nuevo}

$\begin{array}{lll}\text { Shubiluliuma I } & 1380 / 75 / 1335 & 1370 \\ \text { Arnuwanda III } & 1335 / 1334 & 1330 \\ \text { Mursil II } & 1334 / 1306 & 1329 \\ \text { Muwatalis } & 1306 / 1282 & \\ \text { Mursil III } & 1282 / 1275 & \\ \text { Hattusil III } & 1275 / 1250 & \\ \text { Tudhaliya IV } & 1250 / 1220 & \\ \text { Arnuwanda IV } & 1220 / 1192 & \\ \text { Shubiluliuma II } & 1192 / 1190 & \\ \text { Tudhaliya V } & 1190 / ¿ ? & 1200\end{array}$

\section{Estados neohititas}

$11 i ? / 711$

La cronología hitita se presta a inútiles discusiones científicas, que a nada conllevan, excepto casos muy concretos que pueden ser cotejados con momentos históricos perfectamente datados. Cada autor supone una sucesión determinada para los Tlabarnas que, en muchas ocasiones, no siempre son así.

\section{CLASIFICACIÓN ARMAMENTAL ESQUEMÁTICA}

\begin{tabular}{|c|c|c|c|}
\hline Arquitectura militar & $\begin{array}{l}\text { fortalezas } \\
\text { murallas } \\
\text { torres } \\
\text { arietes. } \\
\text { escaleras }\end{array}$ & \multicolumn{2}{|c|}{$\begin{array}{l}\text { fijas. } \\
\text { móviles, de asalto. } \\
\text { compactas } \\
\text { escalas }\end{array}$} \\
\hline \multirow[t]{3}{*}{ Armamento } & \multirow[t]{2}{*}{ ofensivo } & personal & $\begin{array}{l}\text { espada larga } \\
\text { hacha } \\
\text { bidente (¿tridentes?) } \\
\text { mazas } \\
\text { venablos (cortos) y lanzas (largas) } \\
\text { arcos y flechas } \\
\text { ¿hondas? } \\
\text { ¿bumerangs? }\end{array}$ \\
\hline & & plural & $\begin{array}{l}\text { arietes } \\
\text { calderos }\end{array}$ \\
\hline & Defensivo & $\begin{array}{l}\text { cascos } \\
\text { armaduras } \\
\text { petos } \\
\text { cotas de } r \\
\text { placas o } p\end{array}$ & chas \\
\hline
\end{tabular}




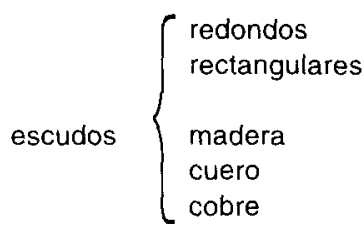

Infantería

$\begin{array}{ll}\text { Caballería } & \left\{\begin{array}{l}\text { propiamente dicha } \\ \text { carros ligeros o de combate } \\ \text { carros pesados o de carga }\end{array}\right. \\ \text { Marina } & \left\{\begin{array}{l}\text { comercial de cabotaje } \\ \text { fluvial } \\ \text { de guerra } \\ \text { barcos genéricos. }\end{array}\right.\end{array}$

\section{UNA APROXIMACIÓN A LA HISTORIA HITITA}

El País de Hatti estuvo situado en el centro de la gran meseta anatólica (figuras $n .^{\circ} 1$ y 2), si bien el imperio que creó se extendía por Asia menor, norte de Mesopotamia, noroeste de Siria y la Fenicia, y el propio nombre de hitita proviene de la Biblia que los cita, indistintamente, como "hijos de Het" e "Hittim", los egipcios como "Ht» y los griegos (Homero) «keteioi». Ellos mismos, en el segundo milenio a.C., se denominaban «habitantes del Pais de Hatti». Ya, en la antigüedad próxima, el mismo Herodoto los reconoce como "los forjadores del hierro". De modo que hay que indicar que su cultura floreció entre los siglos $x x$ al xII a.C., sin que pueda decirse si eran aborígenes o probablemente conquistadores guerreros indoeuropeos que alli se ubicaron como aristocracia militar dominadora de las poblaciones ocupadas, formando una monarquía feudal.

Hacia 1600/1650 a.C. Hatussili I abandona Jusar, ciudad situada en la Anatolia central, aún sin localizar, y se establece en la ciudad de Hattusa, cerca del actual poblado de Bogazköy en Turquía, que se convierte en la capital del imperio hitita y que subsistió hasta su destrucción en 1200 aprox. a.C. Confirma lo anterior lo que es de todos conocido: EI descubrimiento en Tell el Amarna (ciudad de Akhetatón) del archivo diplomático de los faraones Amenhotep III y Akhenatón (Amenhotep IV), mantenido con el rey hitita Shubiluliuma, además de los coincidentes archivos reales en el pequeño poblado de Bogazköy, descubiertos por 


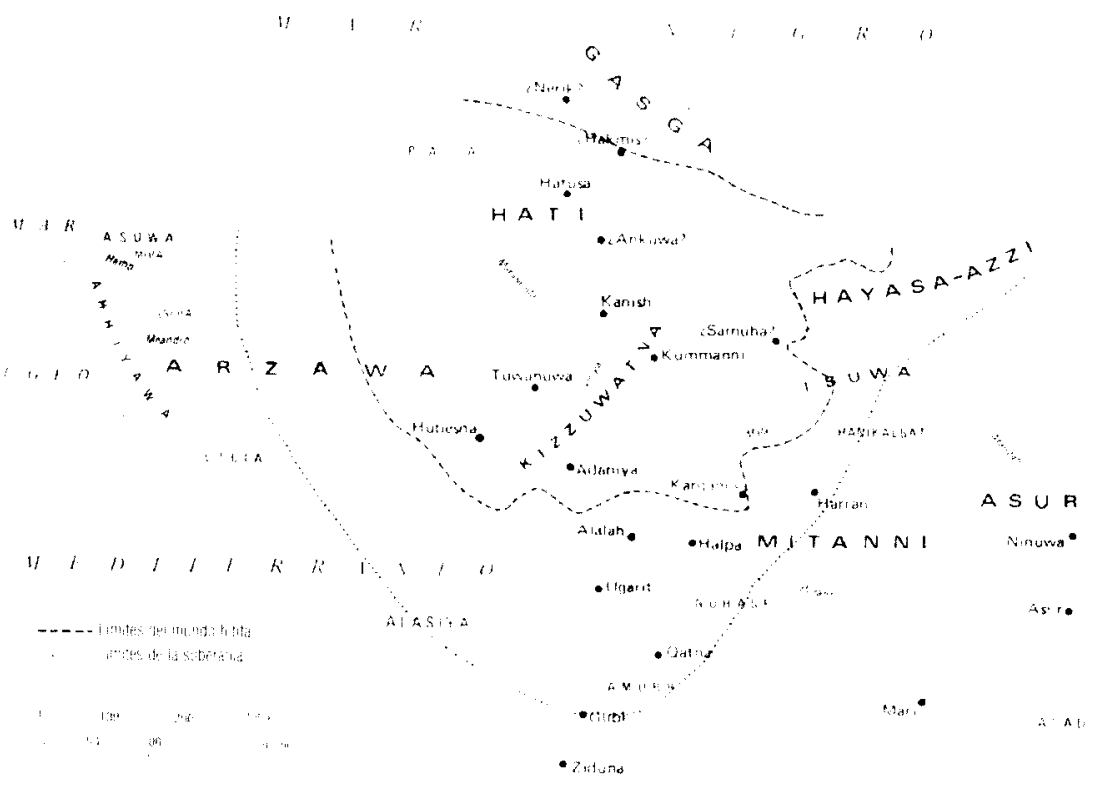

Figura 1

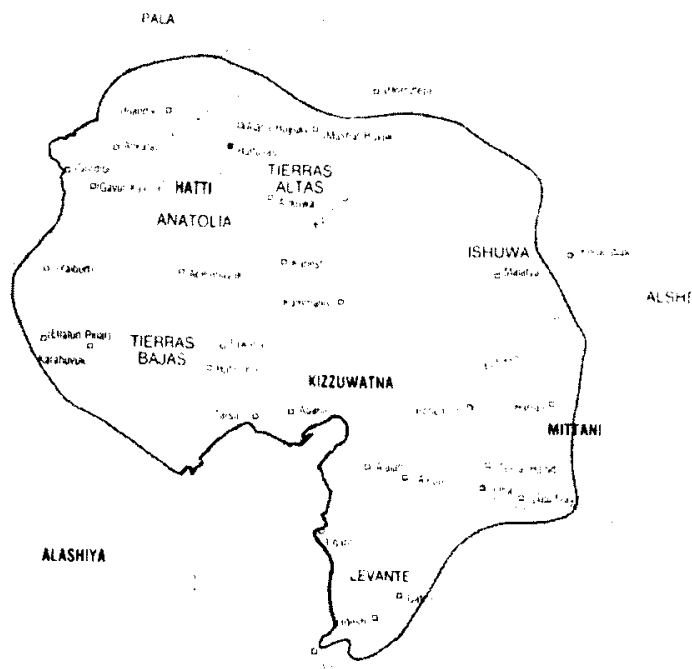

Figura 2 
Winckler ${ }^{1}$, que confirman a este lugar como Hattusas, la capital de Hatti. Los origenes de este pueblo son oscuros. Su lengua pertenece a la familia indoeuropea y probablemente proceden del norte o nordeste por el Cáucaso, quizás a mediados del III milenio a.C. y las primeras ciudades importantes parece que fueron Nesa (Kültepe), en el sur y Zalpa, en el norte, en el Mar Negro.

A juzgar por los descubrimientos escultóricos se nos antoja que los hititas eran muy amantes de la piedra y de los lugares montañosos y rocosos, tallando en ellos grandes bloques de piedra, representativos de sus dioses y reyes, con un frente pulido y con juntas poligonales.

La cronología hitita podemos, a grandes rasgos, dividirla en una época protohitita, ubicada entre el 2000 y 1700 a.C.; es decir desde que los indoeuropeos hititas van penetrando y conquistando la meseta anatólica, a la vez que se fusionan con los aborígenes, y se conforma un antiguo reino o primer imperio hitita, entre los años 1700 a 1500 a.C.; un periodo oscuro de unos 50 años en que parece perderse el rastro histórico y un Gran Imperio o imperio nuevo que va desde el 1380 hasta el 1200 a.C. Entre el $1200 / 1150$ a.C. el imperio hitita se desmorona destruido tanto por los gasgas y frigios como por las oleadas invasoras de los "pueblos del mar" (sabemos que un enorme incendio destruyó la capital, Hattusas, circa 1.200 a.C.). Naturalmente estas fechas son supuestamente aproximadas, por lo que no tienen otro valor que el meramente orientativo.

De modo que el derrumbamiento político de la gran potencia hitita ocurrido alrededor del 1200 a.C. estuvo inmerso en la gran catástrofe generalizada en el Asia menor, con su derrumbe cultural, y cuya causa fue, como hemos dicho las invasiones de los llamados "pueblos del mar", hasta que, en los siglos $x$ al vIII a.C. resurge lo que los historiadores han dado en llamar Imperio Neohitita con los reinos de Tabal y de la frigia primitiva.

Bien es cierto que durante todo el imperio hitita los gasgas, levantiscas y poderosas tribus del norte anatólico mantuvieron una permanente guerra de guerillas con Hattusas poniendo en numerosas ocasiones en dificultades a la capital del imperio.

En contra de lo que cabria suponer el mundo antiguo tuvo una gran capacidad comercial y metalúrgica. El intercambio de lingotes de cobre, bronce, plata y oro, vasijas, aceites, perfumes, grano, etc, está comprobado por

1 WINCKLER, H. Vorläufige Nachrichten über die Ausgrabungen in Boghaz-Köi im Sommer, 1907. Die Tontafelfunde. Mitteilungen der Deutschen Orientgesellschaft XXXV, 1907. Págs. 1/59. 
documentación y por la arqueología submarina. En el caso que nos ocupa la plata procedia de las zonas montañosas de Anatolia oriental y es comprobable a través de la correspondencia diplomática, cruzada entre los faraones egipcios y los monarcas asiáticos, la sempiterna solicitud de envíos de plata que ellos compensan con el envio de oro y marfil. Con la desaparición del Imperio Hitita la plata se rarificó en los mercados orientales y subió el precio, equiparándose su valor al del oro, según manifiesta Maluquer de Motes ${ }^{2}$.

Para Ceram ${ }^{3}$ parece que los hititas ya conocieron el hierro (en hitita "amutum») hacia 1600 a.C. y casi el monopolio de su producción, aunque realmente fue un objeto lujoso con el que no se fabricaban armas de guerra, ya que dada su factura, no podían competir con las de piedra y bronce, sino que su empleo fue para cuestiones ceremoniales o de adorno, y además que su precio sobrepasaba en 5 partes el precio del oro y en 40 el de la plata. Así que, en contra de lo que frecuentemente se escribe, el poderío hitita no estuvo en su armamento de hierro (no utilizado para esa factura) sino en sus carros de combate y en su estrategia.

Por otro lado, el arte de trabajar el hierro, durante mucho, tiempo fue un secreto que pertenecía a los herreros de Kizzuwatua, provincia en la que estaban las montañas del Tarso, que eran ricas en mineral de hierro. Así disponemos de una carta que en el S. XIII a.C. envió el rey hitita Hattusili III a un gobernante contemporáneo (probablemente un monarca asirio), donde muestra cuán estrecha era la supervisión de la industria por parte del Estado, toda vez que Hattusili decía en su misiva que las "dificultades de producción y las escasas existencias de hierro fundido retrasaban la entrega de los artículos solicitados". Esto nos da idea del desarrollo económico, originado por el trueque comercial, junto al pillaje de los campamentos y ciudades enemigas en tiempos de guerra.

\section{LENGUA Y ESCRITURA}

En las ruinas de Hattusas se han encontrado inscripciones en 8 lenguas distintas, y aunque esto no es indicativo de que todas se utilizáran, es probable que la mitad fueran de uso común. Fue Forrer ${ }^{4}$, junto con

Tartessos.- Maluquer de Motes y Nicolau, J.E. Destino. Barcelona, 1984.

Vid. bibliografia no exhaustiva.

FORRER, E. «Die Inschriften und Sprachen des Hatti-Reiches". Mitteilungen der Deutschen Orientgeselischaft. LXXVI. Leipzig, 1922. 
Meriggi ${ }^{5}$ que estudió los jeroglíficos hititas, el que describió las 8 lenguas de los hititas (sumerio, acadio, canesita o hitita propiamente dicho, mitanni, luvita, protohitita - realmente muy rudimentario, empleando afijos y desconociendo las declinaciones ${ }^{6}$ - o el usado por los originarios anatoles, hurrita y palaita). Por su parte Von Soden ${ }^{7}$ expresa que dentro del indoeuropeo las lenguas más vecinas del hitita son el itálico, el celta y el tocario. Una forma tardía del hitita la representa probablemente el lidio, y una forma tardía del luvita es el licio del primer milenio. Pero no sabemos explicar cuándo y dónde, los hititas, que carecian de escritura, adoptaron para su lengua, la escritura babilónica cuneiforme ya antes del 1900 a.C.

En cuanto a su escritura cuneiforme, por los documentos encontrados, se utilizaba el hitita, sumerio y acadio para las relaciones internacionales

El luvita era la lengua hablada en la región de Luviya, en el reino de Arzawa regado por el rio Meandro que desemboca en la costa del mar Egeo. Desde luego parece que el luvita era una lengua más antigua e íntimamente ligada al hitita y cabe incluso que la primera sustituyese a la segunda en época neohitita. Por su parte, en 1925, Friedrich Hrozny descubrió la lengua hablada de los hititas.

\section{TEXTOS HISTÓRICOS}

Aún cuando no nos ha quedado demasiado material escrito hitita, cabe destacar la Proclamación de Anitta que es la crónica histórica del primer rey hitita conocido por nosotros, el Rescripto de Telepinu redactado hacia el 1600 a.C.; el Testamento Político de Hattusil I; Autobiografía (de este mismo rey); Anales y Anales decenales (de Shubiluliuma 1); Anales completos (de Mursil II) y Autobiografia (de Hattusil III). A todo ello hay que añadir los resúmenes históricos y las listas cronológicas encontrados en los archivos reales de Hattusas, así como el llamado "Código Hitita" ".

Las anteriores obras, en los fragmentos que nos han quedado, acreditan a los hititas como importantes historiógrafos, legistas y diplomáticos,

Meficg!. P. "Die Hethitische Hieroglyphenschrift". Zeitscrift tür Assyriolie. XXXIX. N.F.V. Págs. 165/212. 1930

6. En protohitita el nombre de la capital del reino seria Hattus y para el hitita seria Hattusas Hacia el 1800 a C.los nesitas utilizaron el nombre hattili para describir a los hititas, mientras la biblia los llamó heteos y los egipcios kheta.

WOLFRAM VON SODEN. Profesor de antigüedades orientales de la Universidad de Münster. haustiva. 
sobre todo, respecto a esta última materia, el cotejo que podemos hacer de la profusa correspondencia, sobre todo con Egipto.

También tenemos "El mito del reino celeste" ${ }^{9}$, la "Canción de Ullikummi»" y el "Tratado de hipología» cuya autoría se supone al hurrita Kikkuli, experto en caballos.

\section{EL EJÉRCITO}

Fundamentalmente estaba formado por los ejércitos de mar y tierra. En éste se pueden distinguir la infantería, la caballería, los arqueros y los carros de combate ligeros. Ignoramos los grados de la marinería y si los arqueros estaban integrados en la caballería, la infantería o era un cuerpo independiente.

Al frente del ejército estaba el rey, aunque ignoramos si participaba directamente en la batalla o, como en el caso de Hattusili I en el asedio a Ursu, aliada de los hurritas, donde el Tlabarna dirige las operaciones bélicas desde Lawazantiya, un lugar seguro en las estribaciones del Tauro, y comandaban las tropas, entre otras graduaciones, cargos militares como "el jefe de los carros del ala derecha", "el jefe de los carros del ala izquierda", "el jefe de infantería del ala derecha", "el jefe de infantería del ala izquierda", etc.

Los diversos autores se muestran de acuerdo en que el Estado hitita dispuso de una fuerte organización militar y de ahí deducen la severa disciplina de que estaba adornado el ejército. La realidad histórica es que sólo nos podemos basar, tanto en los textos literarios e históricos que nos han quedado, como en su "código" (la rebelión se castigaba con la pena de muerte) y en lo que podamos vislumbrar en las ruinas arqueológicas, así como en los documentos egipcios, fundamentalmente los referidos a la batalla de Qadesh, no muy de fiar por cuanto a su exageración refiere el relato que conocemos a través de diversos templos ${ }^{10}:$ : 37.000 infantes y 3.500 carros de combate" (si cada carro transportaba 3 hombres, hace un total de 47.500 hombres, como mínimo ${ }^{11}$, cifra harto inverosímil si debemos añadir la intendencia y tropa auxiliar que ello supone). Gurney ${ }^{12}$

CECILIO, L. Mito, Semántica y realidad. Madrid, 1970.

Ramesseum en Luxor, Karnak, Abu Simbel o Abydos.

Según estimaciones de De Bruyn (The Battle of Qadesh: Some Reconsiderations), Goetze (Zur Schlancht von Qadesh) y Hicks (Los hititas)

12 Vid. Gurney, Bibliografia no exhaustiva. 
asegura que «la clase militar gozaba de grandes privilegios". Pero lo cierto es que esta aseveración es válida para todos los tiempos, correspondan a pueblos antiguos, medievales... o modernos.

Sin duda su ejército se compuso de 4 cuerpos plenamente diferenciados: a) los guerreros profesionales formados por diversas graduaciones militares de jefatura y tropa, ocupando fortalezas fronterizas, principalmente (tal es el caso de Qadesh, Karkemish o Alepo); b) los guerreros ocasionales formado por glebas de colonos que, al concluir la campaña bélica volvían a sus tierras como campesinos que eran; c) por tropas auxiliares de territorios, en su momento amigos o unidos por pactos, así como de territorios ocupados o conquistados, incluso grupos a sueldo como mercenarios y, por último, d) el ejército personal del rey, o «Gran Tlabarna o Gran Rey amado del dios" que se encontraba, normalmente, en la capital del reino, Hattusas. Por otra parte, las campañas guerreras se hacían, como en toda la época antigua, en primavera, verano y otoño, pero no en invierno, por cuestiones obvias de táctica, estrategia y logística militar, reñidas con la previsible meteorología.

Además de todo ello disponian de un cuerpo especializado que hoy llamaríamos de «ingenieros» para la hechura y colocación de puentes con qué vadear rios y sortear obstáculos amurallados, así como de escalas trenzadas, de arietes y torres móviles de asalto hechas de madera, ante la defensa de las murallas enemigas ${ }^{13}$.

$Y$ es conveniente recordar que, precisamente, en las guarniciones fronterizas del imperio el jefe de la guarnición o fortaleza no solamente ejercia sus propias funciones militares, sino las civiles, jurídicas y las religiosas ${ }^{14}$.

Las armas de la infantería se componían fundamentalmente de espada y escudo, aunque otros cuerpos de infantes llevaban hacha y jabali-

Y que conocemos a través del texto CTH 7, que describe el asedio de Ursu, cuando entre otras cosas dice: “Asi habló el rey: ...Entonces rompieron el airete... ¡Haced un ariete al modo de los urritas y colocadlo en posición!... ¡Cortad un gran ariete de las montañas de Hassu y colocadlo en posicion! ¡Vamos a traer una torre de asalto y un ariete! ... En Hatti no hay ninguna torre de asalto ni ariete alguno; ya que él está en las inmediaciones, vayamos a exigírselos». De modo que las técnicas querreras eran entre otras, el uso de arietes, torres de asalto y formación de terraplenes, similares a los "agger" romanos mucho más tarde, para defenderse de los ataques enemigos.

1.4 Se puede conocer a través del texto CTH 261.1,2,3 que describe las instrucciones a los comandantes de puestos fronterizos y que, entre otras cosas, dice: "Si alguien inicia un pleito por medio de una tablilla sellada, el comandante de puesto fronterizo deberá juzgarla de acuerdo con la ley y decidir lo recto. Si el caso se vuelve extenso, lo enviará a presencia de Mi Sol» (el rey). "Además, el comandante del puesto fronterizo debe consignar los objetos rituales de los dioses y enviarlos ante Mi Sol". 
na. Las de la caballería arco y flechas, además de espada. Los carros, fundamentalmente arqueros y lanzadores de jabalina.

Desconocemos si usaron hondas y bumerangs, pero presumiblemente lo hicieron. Téngase en cuenta que durante mucho tiempo tuvieron relaciones diplomáticas con Egipto, y también crisis de influencia bélica por el dominio de reinos-tapón, todo lo cual tuvo que dar como consecuencia un intercambio de ideas sobre armamento, táctica y estrategia militar. $Y$ el ejército egipcio utilizó frecuentemente esas armas (figura $n .{ }^{\circ} 3$ ) donde en la batalla naval contra los "pueblos del mar» que aparece en la tumba de Ramsés III, en Medinet Habu, al oeste de Tebas, se observan honderos en el barco egipcio contra el barco enemigo. Dos aparentes honderos se pueden describir: el de la proa del buque egipcio y el que se encuentra con los brazos extendidos, tras el arquero, en el mástil. Sus manos derechas se encuentran en actitud de lanzar la honda (aunque también podria tratarse de amagos de golpear con una maza esférica).

\subsection{Arquitectura militar (fortalezas, torres y murallas)}

La arquitectura militar hitita se basa en dos principios: a) La monumentalidad que acompañaba a las construcciones de aquel pueblo, y b) La necesidad defensiva en un pueblo que se asienta en tierras no propias, sino a las que llegan como conquistadores, no siempre por la fuerza, sino

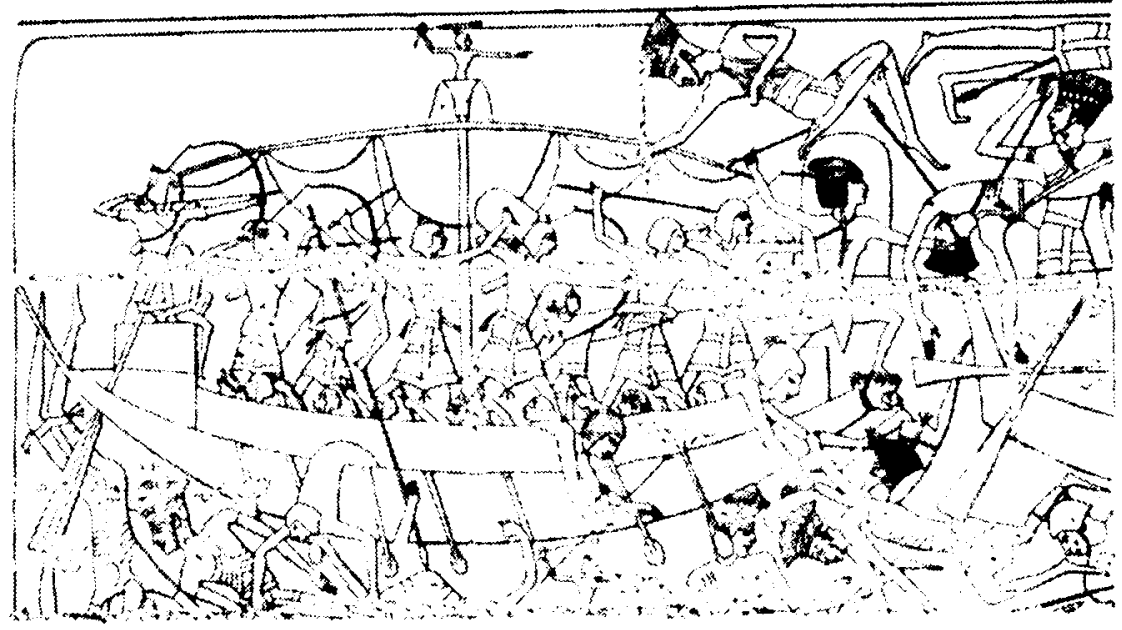

Figura 3 
también como campesinos que se instalaban pacíficamente, y que tienen un largo periodo histórico de extensión y dominio.

De ahí que sus ciudades se encontraban rodeadas de sólidas murallas y muros de ladrillo crudo, pero ambas cimentadas sobre cimientos rocosos, formando un conjunto de muy amplia anchura.

Un ejemplo paradigmático es la ciudadela de Sendjirli, descubierta por Karl Humann en 1888, que está dividida en 5 secciones independientemente fortificadas y casi prácticamente inexpugnables (figura $n .{ }^{\circ} 4$ ) y cuyo descubrimiento nos describe Ceram ${ }^{15}$.

Su técnica militar de construcción se caracteriza por la aparición de la doble muralla con frecuentes poternas, como la enorme de Bogazköy, con grandes torres aportaladas a fin de garantizar la defensa de las ciudades, como se observa en la figura $n^{\circ} 5$ (según la interpretación que de las ruinas hace Ducoloner), sin olvidar la estética armónica que se observa en la modélica puerta de Alaka Hüyük con ortostatos decorados con bajorelieves. Ahí, precisamente, se aprecian los zócalos ciclópeos de piedra, sin olvidar la construcción del primer puente que se conoce en la historia, uniendo a

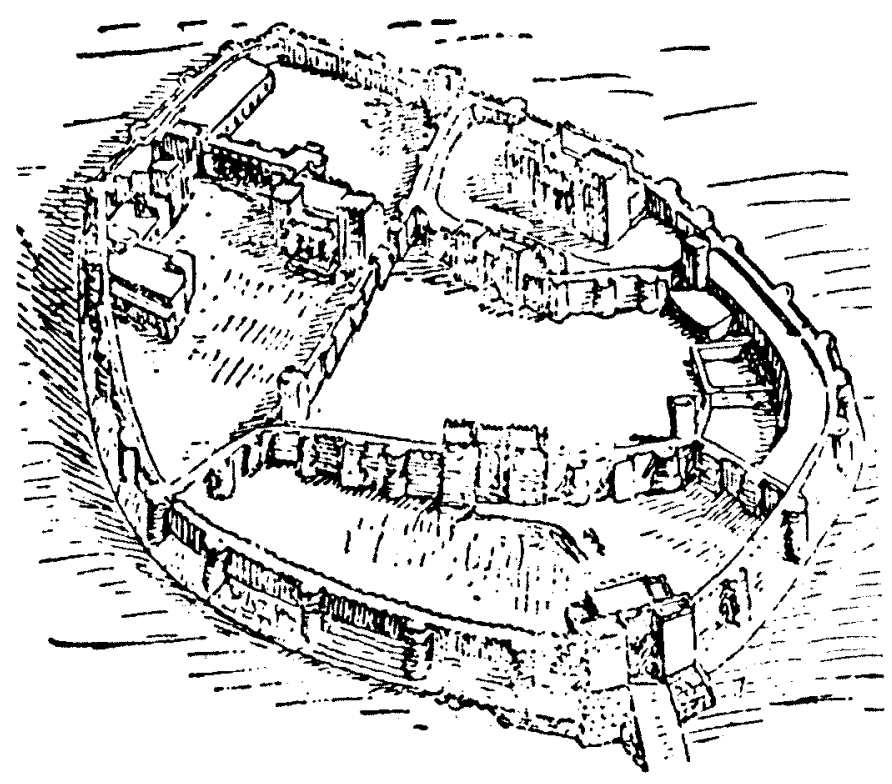

Figura 4

Vid bibliografía no exhaustiva. 


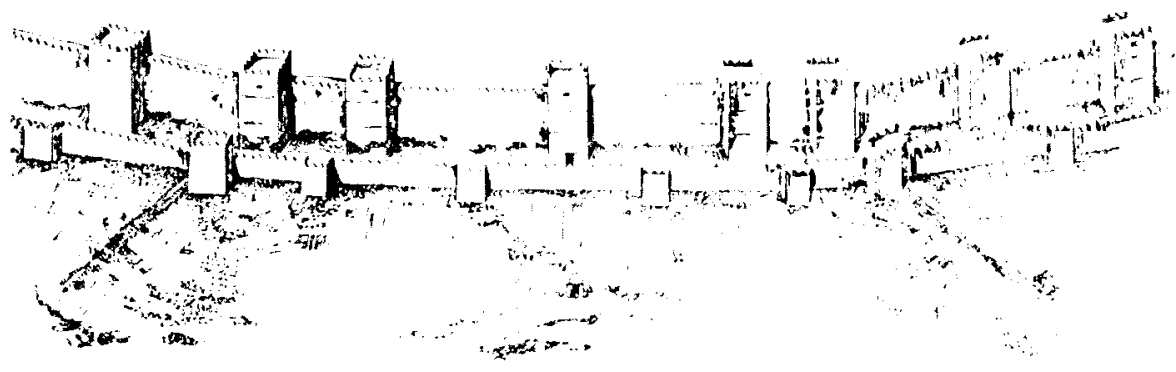

Figura 5

través del precipicio del occidente de Hattusas la ciudad con la muralla, como ya apuntó Sommer ${ }^{16}$.

El esquema de la anterior figura denota la construcción de un sistema amurallado "doble». El exterior o de vanguardia más bajo y apuntalado con torreones a igual altura que la muralla, cada determinada distancia, intercalados con otros más potentes en su estructura defensiva. Son ciegos y se trata de la "avanzadilla» de choque sobre los posibles agresores. Su defensa es, sin duda, el lanzamiento de jabalinas, flechas y grandes pedruscos, ante el asalto con escaleras de mano que están documentadas en dibujos egipcios desde la XII dinastía.

El interior, o de retaguardia, es mucho más alto y sus torreones superan la muralla dando una sensación de superfortaleza inexpugnable. Con esa táctica defensiva de sus ciudades, aún cuando sus enemigos dispusieran de torres de asalto, éstas no podían o lo harian con suma dificultad, transpasar esa primera barrera, con intención de atacar la segunda, mucho más alta. Cuando menos su altura puede ser de 3 o más pisos, teniendo un completo dominio sobre la muralla y torreones de vanguardia, para el caso de ser conquistados. Este sistema de recinto amurallado no fue superado ni mejorado ni tan siquiera en nuestra Edad Media, lo que denota el grado de ingeniería militar avanzada de los hititas cuando querían fortificar una ciudad-fortaleza.

\footnotetext{
i6 Vid. bibliografía no exhaustiva.
} 
Abunda en nuestro anterior punto de vista la figura $n .^{\circ} 6$, que es el fragmento de una tinaja de cerámica que se encontró en Hattusas, donde se aprecia un modelo almenado con ventanales que superan las almenas de la muralla, donde se observan los extremos de las vigas sobre las que se sustenta el piso, y que es confirmado en la figura $n .^{\circ} 7$ con los 3 pisos o alturas antes expresados y que denota la típica arquitectura militar de Urartu, ya que este modelo se encontró en Toprakkale.

En la figura $n .{ }^{\circ} 8$ puede apreciarse el sitio y asalto de una ciudad almenada donde los asaltantes, ya encaramados en lo alto de la muralla, prenden fuego a la ciudad asaltada. La existencia de escaleras compactas o fijas está datada, al menos, desde el S. xxIv a.C. En una tumba de Dishasha, al sur de Herakleópolis se ve el relieve de la figura $n .^{\circ} 9$. Tengase en cuenta que el uso

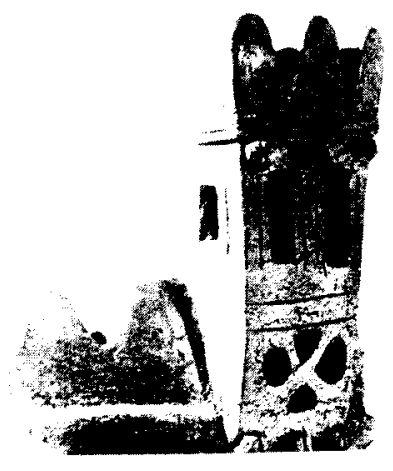

Figura 6

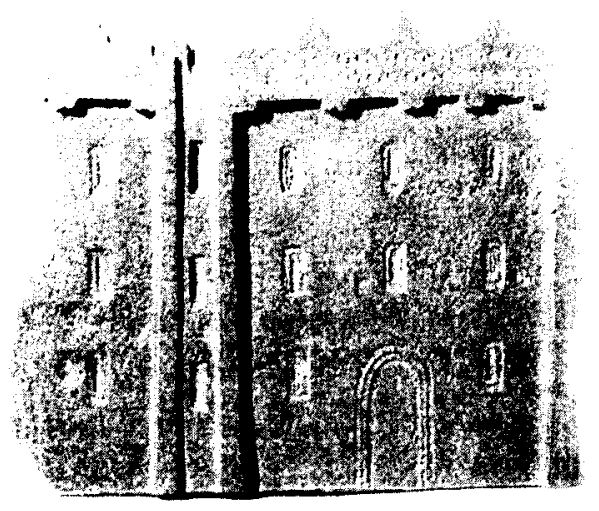

Figura 7 


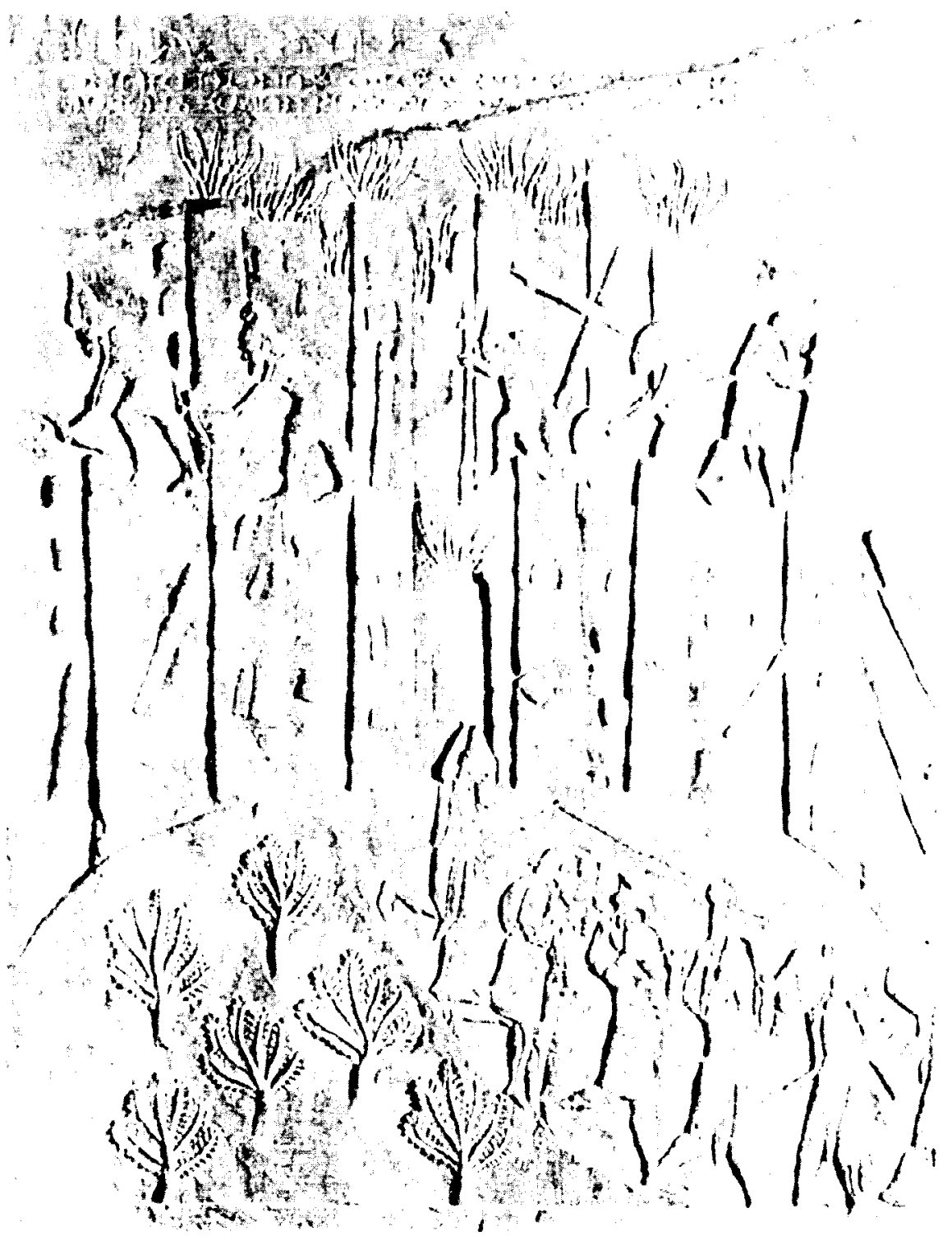

Figura 8 


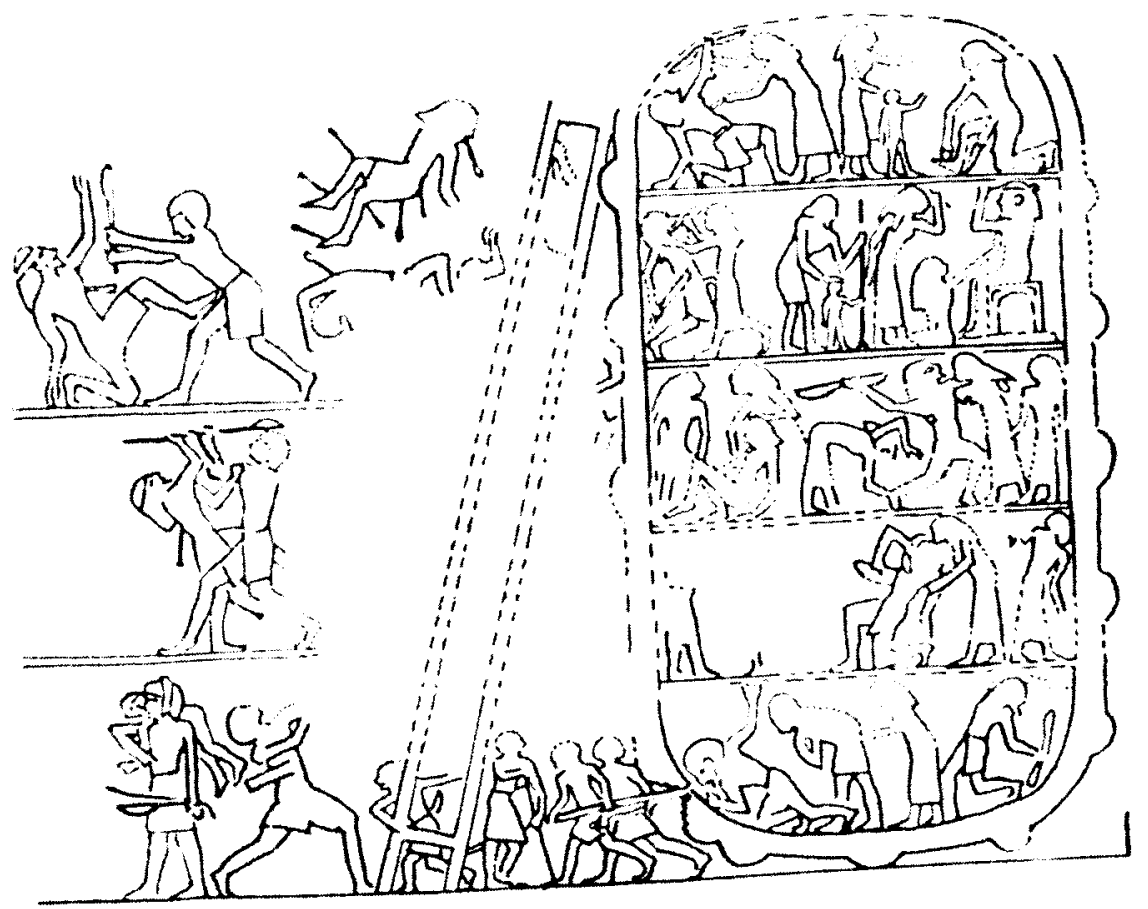

Figura 9

de este tipo de escaleras para acceder al piso superior de las viviendas, tanto en Egipto, Sumer, Hatti, etc, se hacía desde los tiempos más antiguos ${ }^{17}$.

\subsection{Armas ofensivas y defensivas}

Denominamos armas ofensivas aquellas que se dedican al ataque del enemigo, más o menos cercano, incluso en el cuerpo a cuerpo. Así tenemos las espadas, hachas, bidentes, mazas, venablos, arcos y flechas. Algunas también encajan en el capítulo de armas defensivas, como las hachas o las mazas. Pero su componente parece más bien ofensivo que defensivo. Respecto a los grandes calderos de cobre para contener grasa animal fundida con que impregnar pequeñas teas atadas a la punta de las

Vid. Alonso y Royano, F. La ciudad y el ciudadano en Egipto. ETF, serie II, n. 10. Historia Antigua. UNED. Madrid, 1997. 
flechas, es una suposición verosímil, dada la frecuente constatación de incendios en las ciudades asaltadas (incluida, en su momento, Hatussas). Y aunque la certeza no la tengamos, si constan, arqueológicamente hablando, estratos de fuertes incendios, sean originados tras el asalto o con motivo del asalto. $Y$ defensivas, como puñales, cascos, escudos, petos, cotas de malla y armaduras, cuya única utilidad es, precisamente, la defensa del portador de las armas ofensivas.

En la figura $n .{ }^{\circ} 10$ podemos observar el relieve rocoso que se encuentra esculpido en una de la puertas de la ciudad de Hattusas, que se la conoce hoy como "puerta del rey", de un guerrero hitita, probablemente perteneciente al cuerpo de infantería, portando un alto casco con orejeras, un hacha de único filo y una espada.

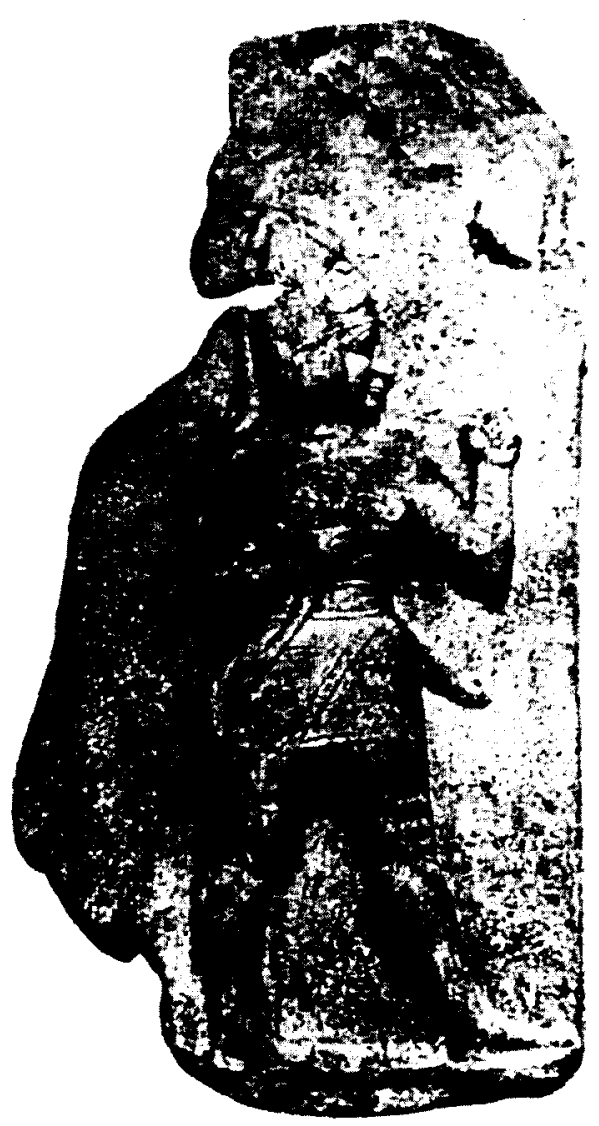

Figura 10 
4.2.1. Ofensivas. Entre las ofensivas figura la espada larga, primero de bronce y, mucho más tarde, de hierro (apenas usadas por los hititas en época muy tardía), las hachas de diversa factura y material, los bidentes, las mazas, los venablos (cortos) y lanzas (largas) y los arcos y flechas de madera, con punta endurecida por el fuego o bien de silex, hueso o cobre, fundamentalmente. Desconocemos si utilizaron la honda con proyectiles de piedra o cobre, ya que no sabemos de iconografía sobre tal arma arrojadiza, ni tampoco el bumerang, como ya hemos indicado más arriba.

4.2.1.1. Espadas. a) Arma ofensiva de no menos de $100 \mathrm{cmts}$ de longitud, de hoja estrecha y curva, con empuñadura coronada con pomo oblongo, y colocada en funda, según se observa en la figura $n .^{\circ} 11$. Puede que su uso estuviese destinado a la caballería, por cuanto se necesitaba un arma ofensiva más larga para llegar al enemigo desde la montura.

b) Arma ofensiva larga, de no menos de $100 \mathrm{cmts}$ de longitud, de hoja más ancha que la anterior, con empuñadura aparentemente sin coronar, colocada en funda recta ceñida al cinturón por una cincha, según figura $\mathrm{n} .{ }^{\circ} 12$ y $n .{ }^{\circ} 18$. Puede que su uso estuviese destinado a la caballería.

c) Arma ofensivo-defensiva, de unos $50 \mathrm{cmts}$ de longitud, de hoja ancha, con empuñadura acabada en pomo bifronte, colocada en funda recta y directamente a la cintura. Según figura $n .^{\circ} 13$.

d) Arma ofensiva larga, de no menos $100 \mathrm{ctms}$ de longitud, de hoja estrecha, con empuñadura acabada en pomo bifronte, según figura $n .^{\circ} 14$.

e) Arma ofensivo-defensiva de unos $80 / 100 \mathrm{cmts}$ de longitud, curva en su mitad distal (notese que de la cintura de la figura pende una vaina, aparentemente recta al estar libre, lo que indica que no era rígida, según figura $n .^{\circ} 15$.

f) Arma defensiva corta, "espada-hoz" de unos $40 \mathrm{cmts}$ de longitud, curva y prominente en su mitad distal (nos recuerda las hoces actuales) sin apreciarse más detalles, según la figura n. ${ }^{\circ} 17$. Se aprecia mejor el tipo de "espada-hoz" en la copia hecha en el santuario de Yasilikaya, fundado por Tudhaliya III, y que a juicio de Otten ${ }^{18}$ se trata de una procesión de dioses con altos gorros conicoformes (figura $n .^{\circ} 15$ ).

g) Arma ofensiva, larga, recta que se aprecia en ambas figuras. Figura n. ${ }^{\circ} 18$.

18 OTten, H. "Zur Datierung und Bedeutung des Felshellingtums von Yasilikaya". Zeitschrift für Assyriologie N.F. xxiv. 1967. Págs. 222/240. 


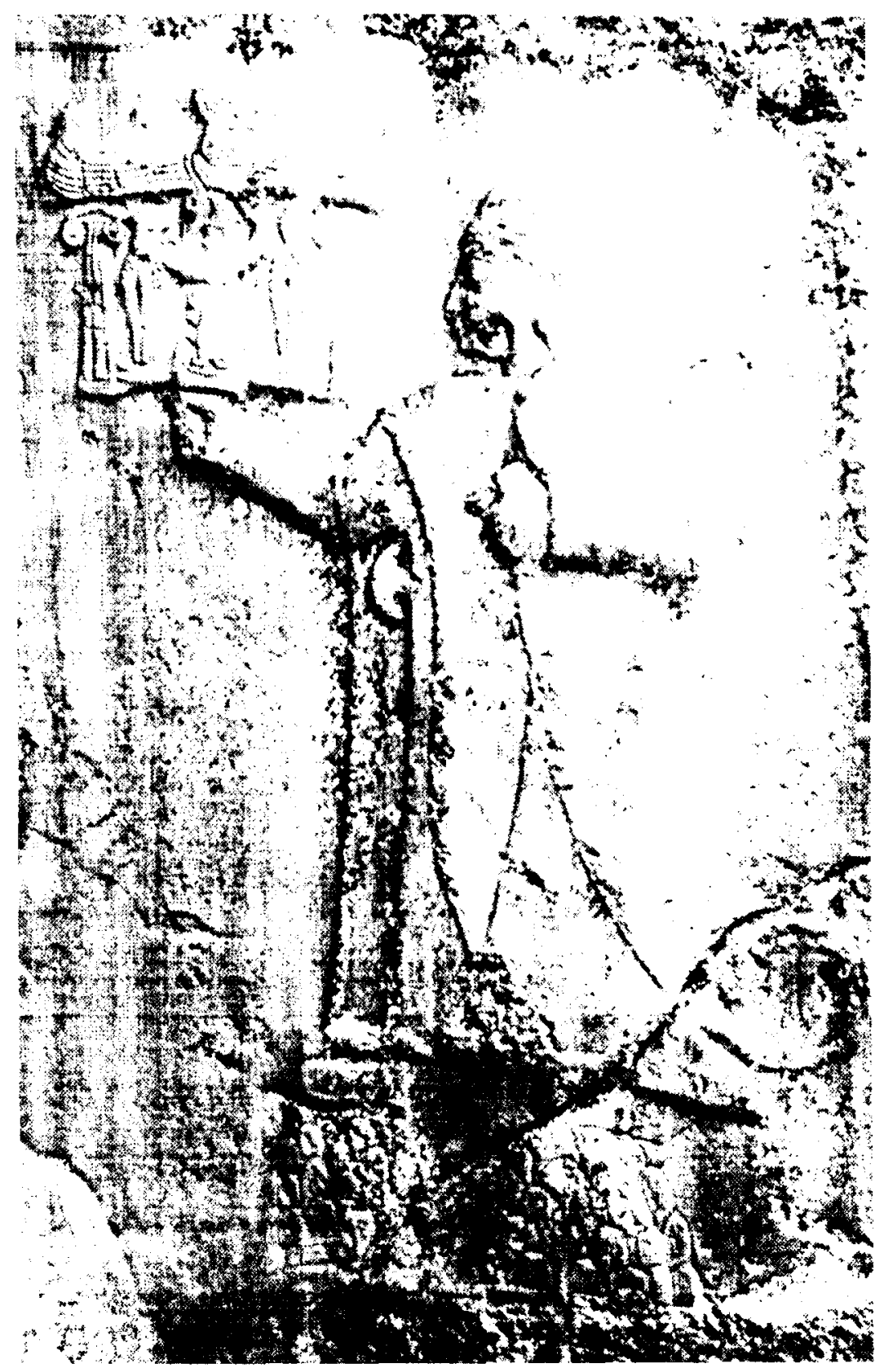

Figura 11 


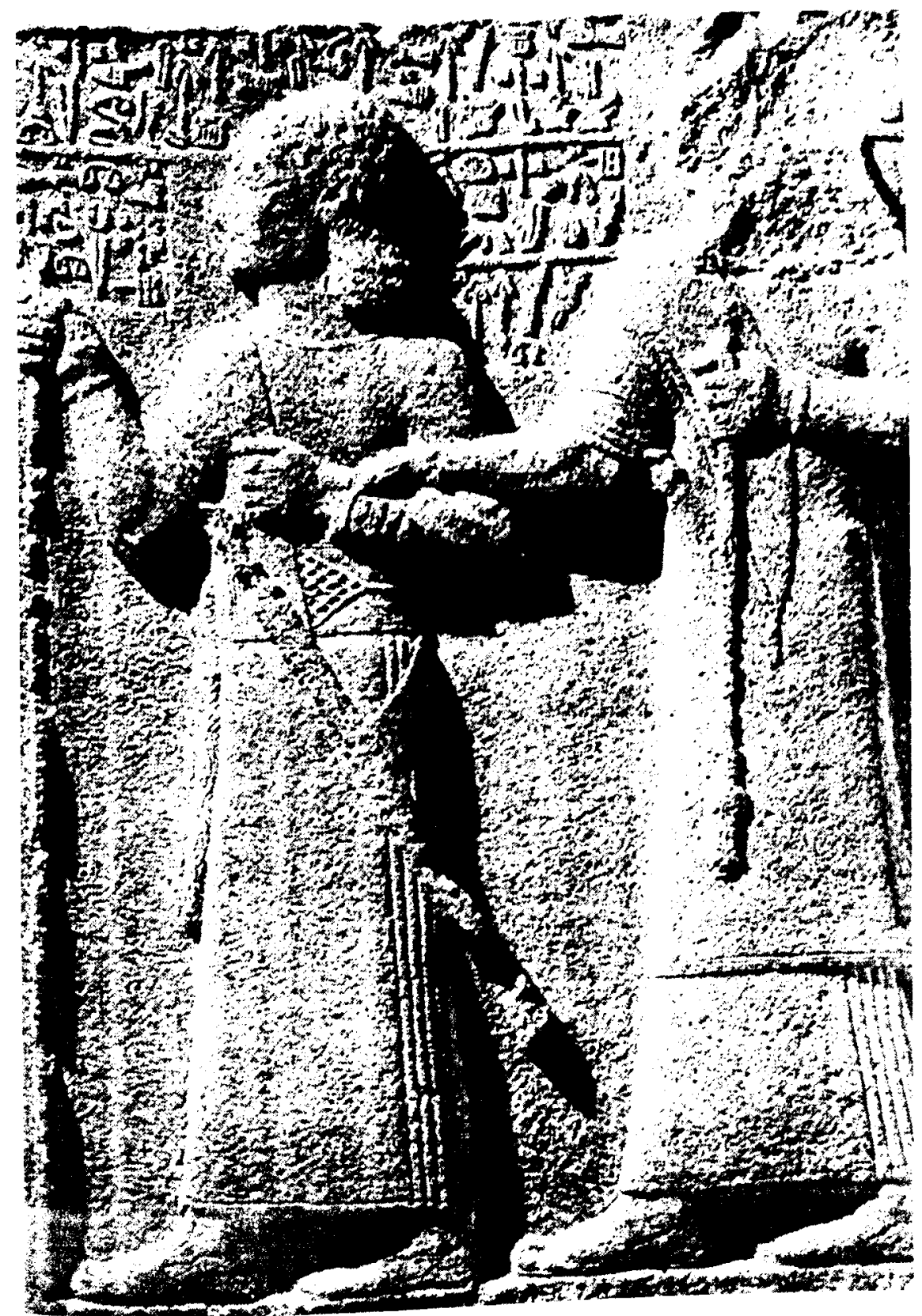

Figura 12 


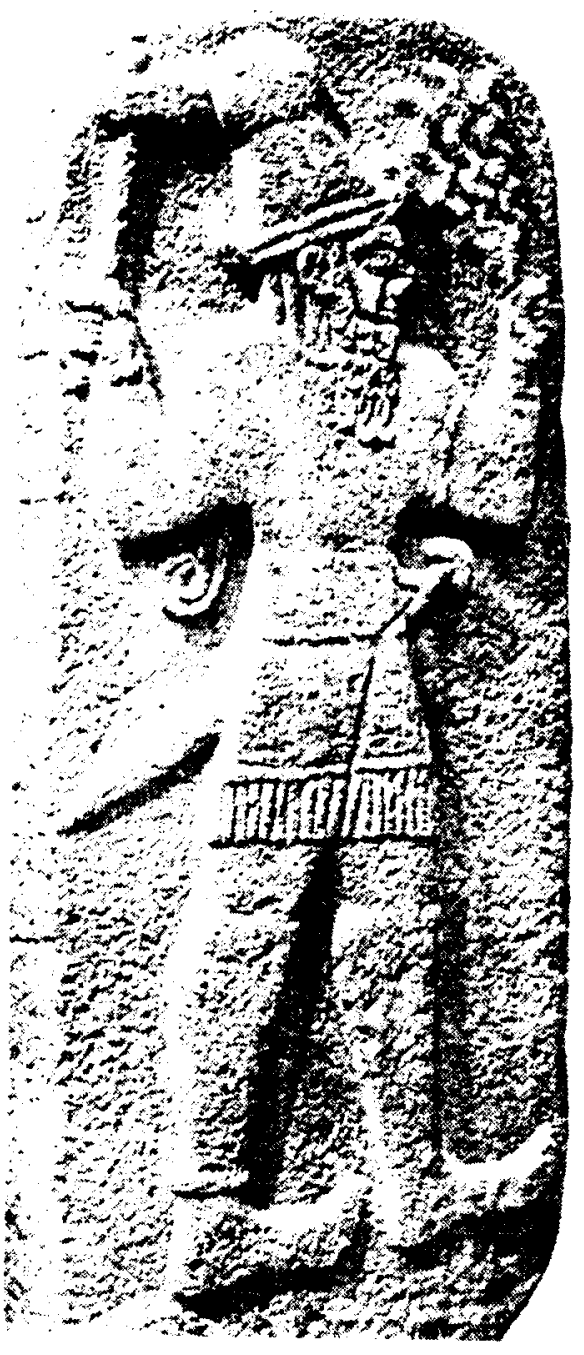

Figura 13 


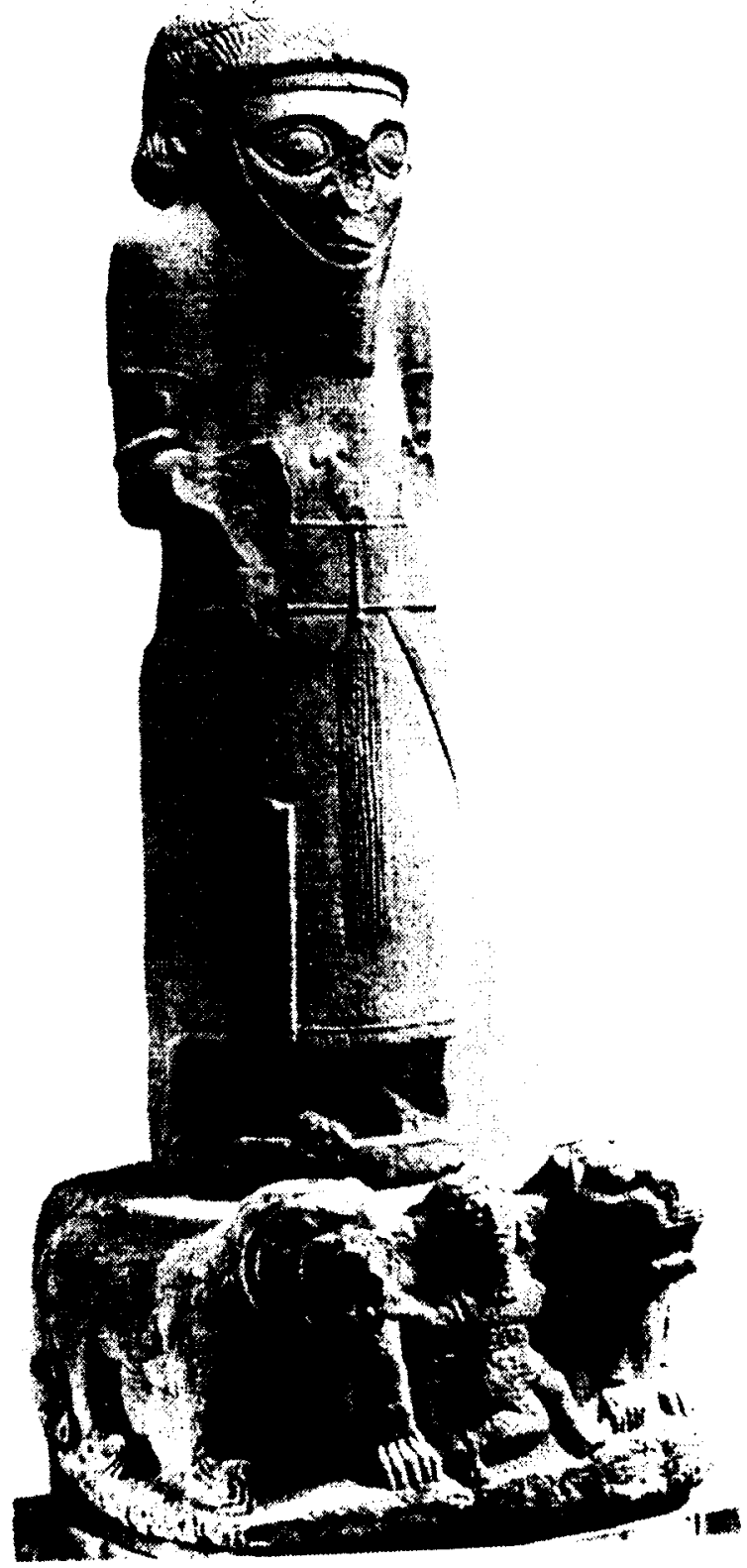

Figura 14 


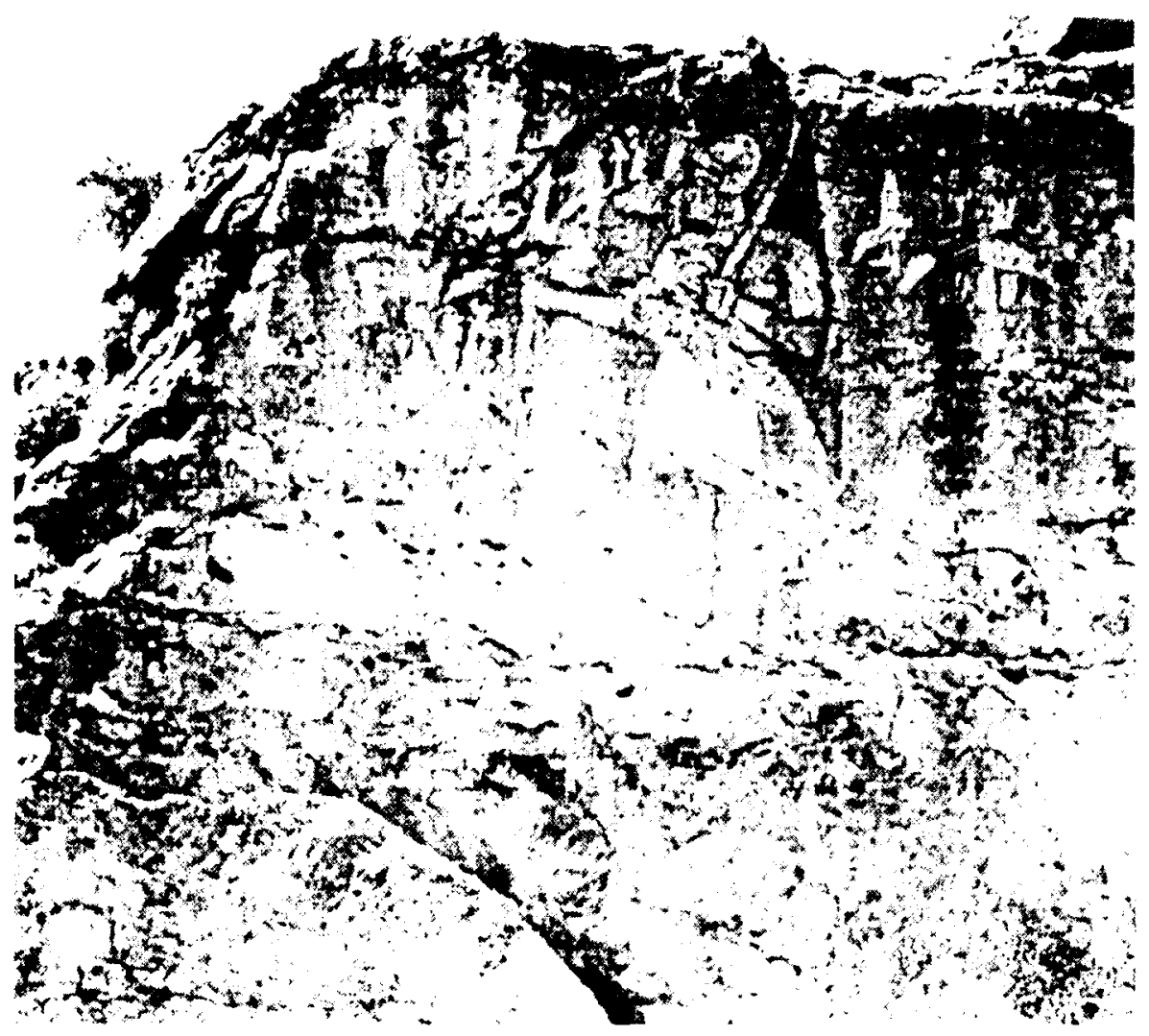

Figura 15

4.2.1.2. Hachas. Según la presente iconografía, las hachas podian ser de piedra pulimentada, silex (lo mismo que las puntas de flecha), bronce fundido o hierro, y se montaban en mangos de madera que eran incrustados en un agujero que horadaba el cuerpo del hacha o en otros casos éste era sujetado fuertemente a través de correas de cuero o, incluso. como en el caso de la figura $n .^{\circ} 19$, se remachaban, mientras que otras alargadas y estrechas como este ejemplo egipcio ${ }^{19}$ (figura $n .^{\circ} 20$ ) se unian al mago de madera por medio de correas de cuero, como hemos dicho más arriba.

Hacha decorada con los cartuchos del Faraón Ahmose (1550/1525 a.C.), donde se aprecia la hoja broncínea unida al mango de madera por medio de cintas de cuero entrelazado, y que se encuentra en el Museo Egipcio de El Cairo. 


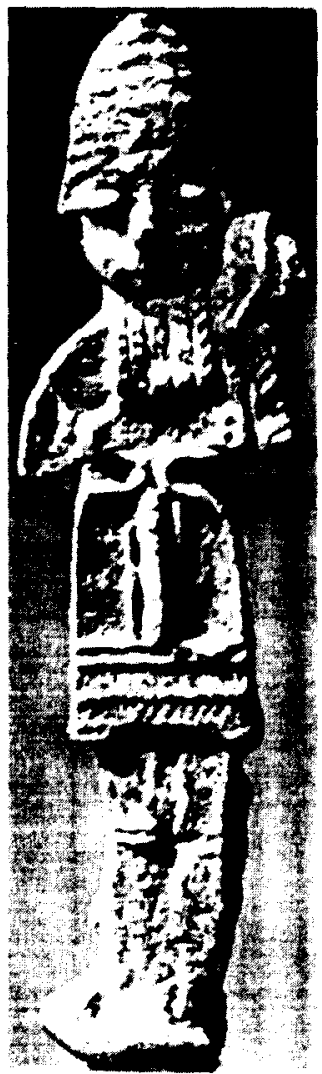

Figura 16

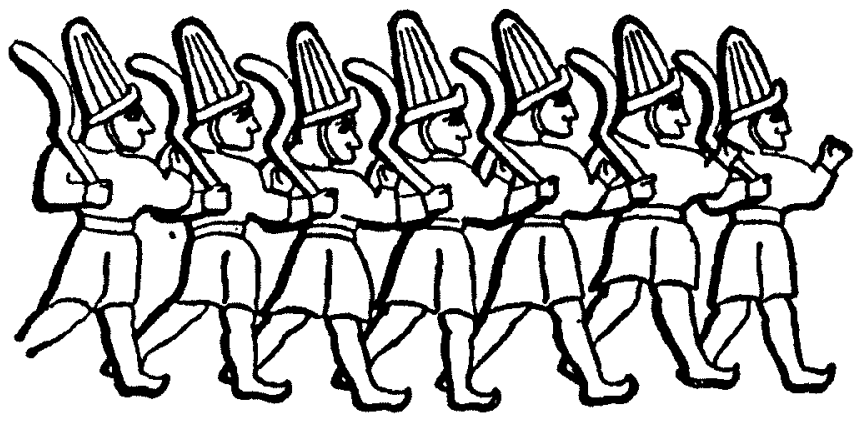

Figura 17 


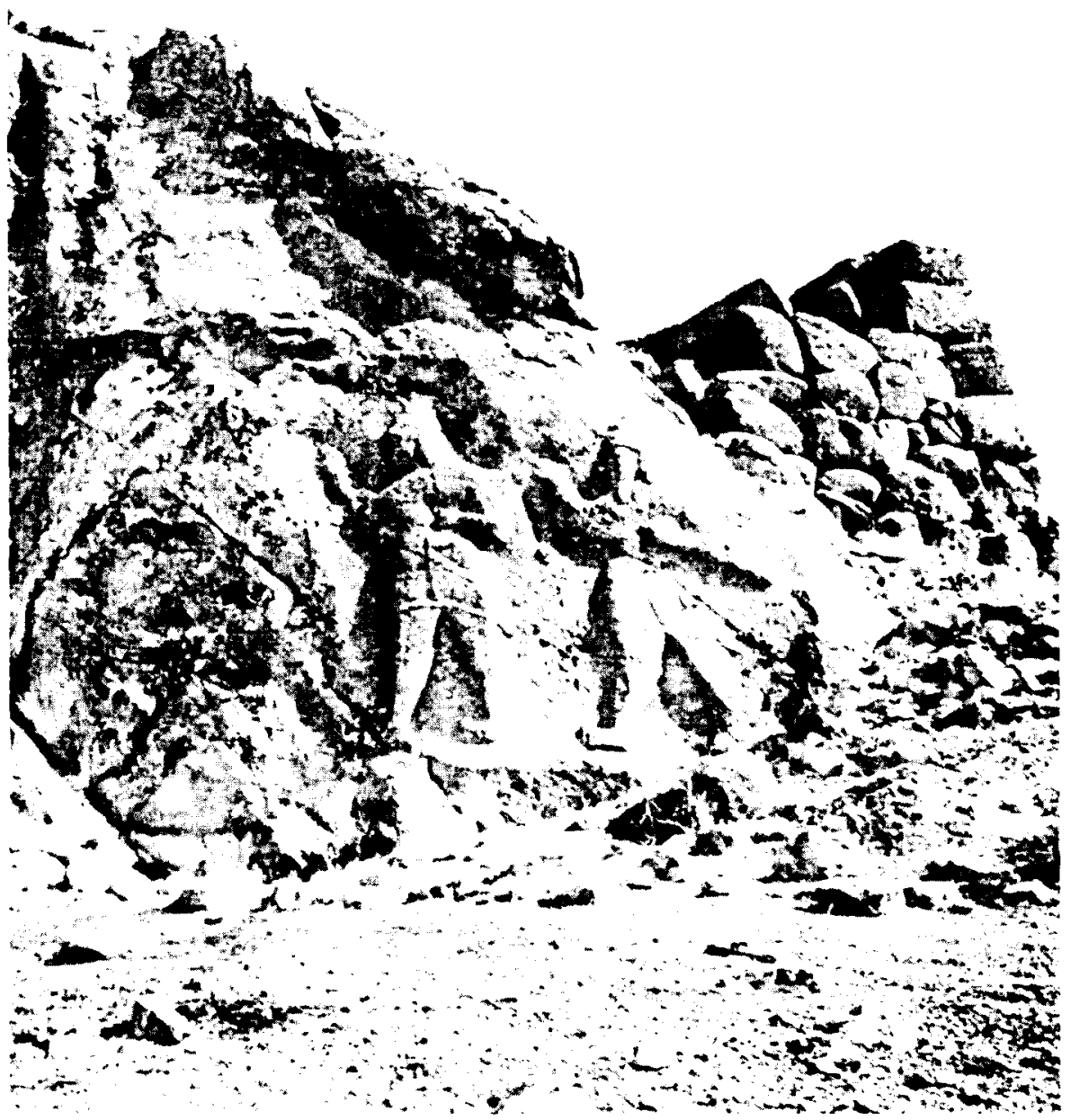

Figura 18

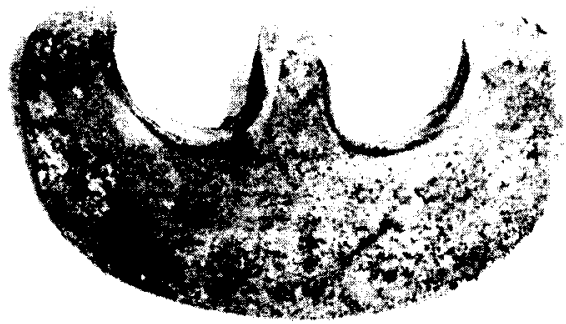

Figura 19 


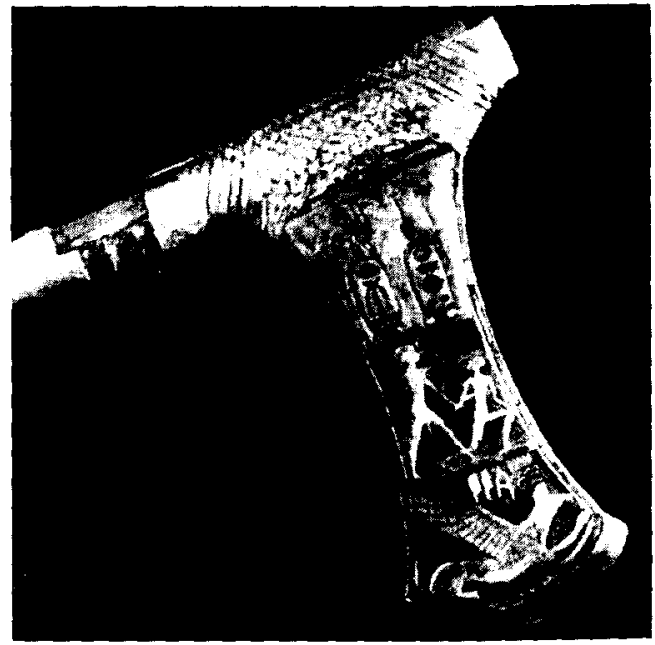

Figura 20

a) Arma ofensiva de corte curvo incrustado en el centro del largo mango. Figura $n .^{\circ} 21$.

b) Arma ofensiva, probablemente de piedra, con mango corto. Figura n. ${ }^{\circ} 13$.

c) Arma ofensiva, de corte curvo y colocada en la parte central de un largo mango (figura $n .{ }^{\circ} 22$ ), y que es idéntica a la de la figura $n .^{\circ} 21$.

d) Aparente desfile militar ante el "Tlabarna» ${ }^{20}$, portando al hombro hachas de facies aplanada, pero que también podría tratarse de carracas ceremoniales en un rito religioso, si nos guiamos por la figura de la izq. (¿un Tlabarna o un dios?), de pie y vertiendo un líquido sobre una jofaina. Figura $n .^{\circ} 23$. También cabe interpretar este relieve en que la figura que hay frente al supuesto sacerdote (si esa fuese la versión correcta), porta en su mano derecha 3 pequeñas mazas. Por su parte la figura $2 .^{a}$, por la derecha de la citada figura, porta en su mano derecha una gran maza ovoidea, similar a la de la figura $n .^{\circ} 28$.

e) Arma finamente tallada que se nos antoja puramente ceremonial. Quizás también, para uso de un soberano. Figura n. 24.

20 Nombre genérico que se daba al rey, acompañado del epiteto "Gran Sol" o "Mi Sol", desde 1650 a.C. 


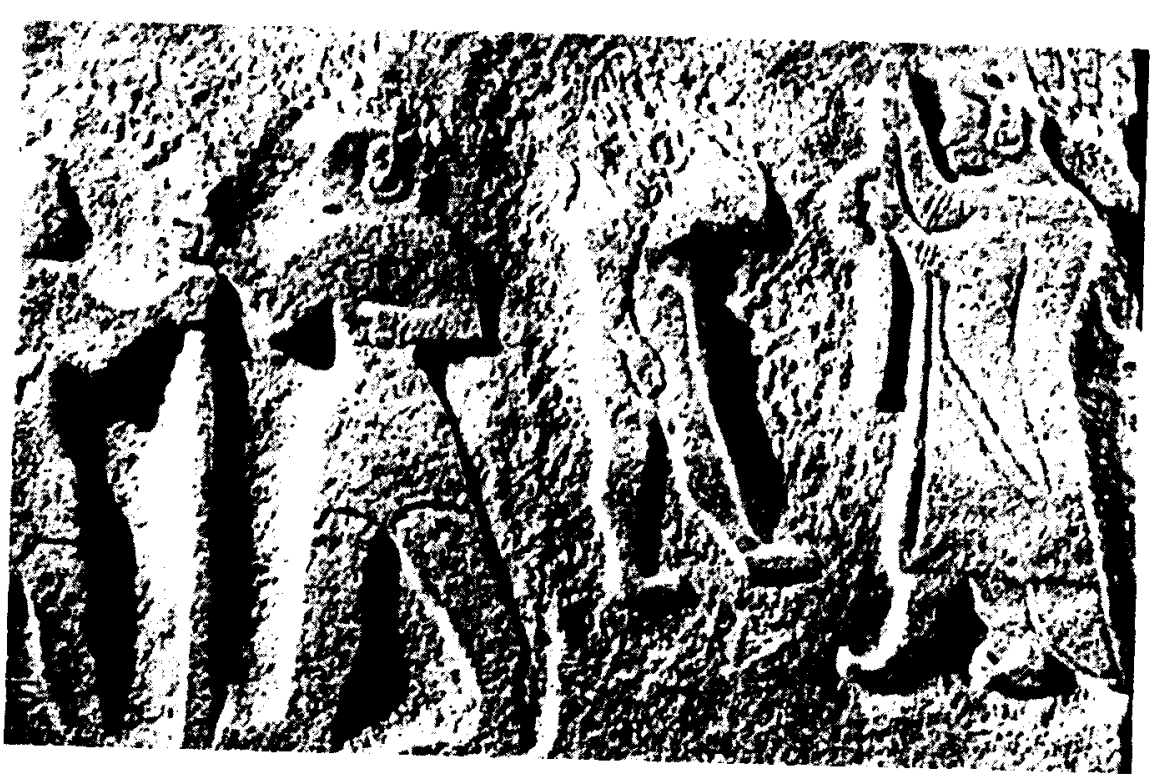

Figura 21

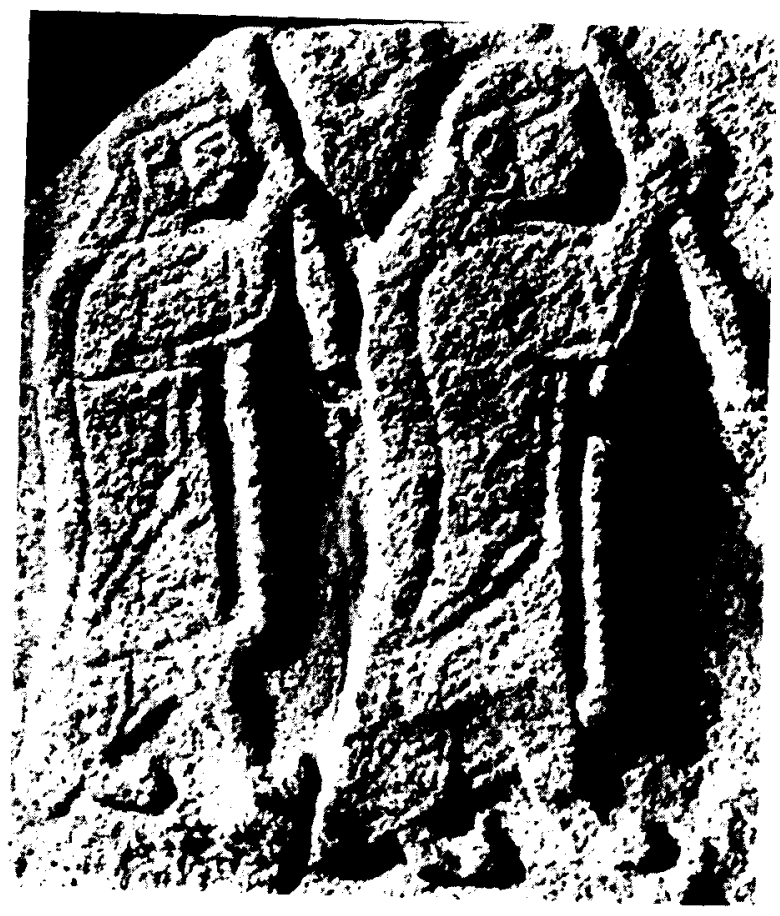

Figura 22 


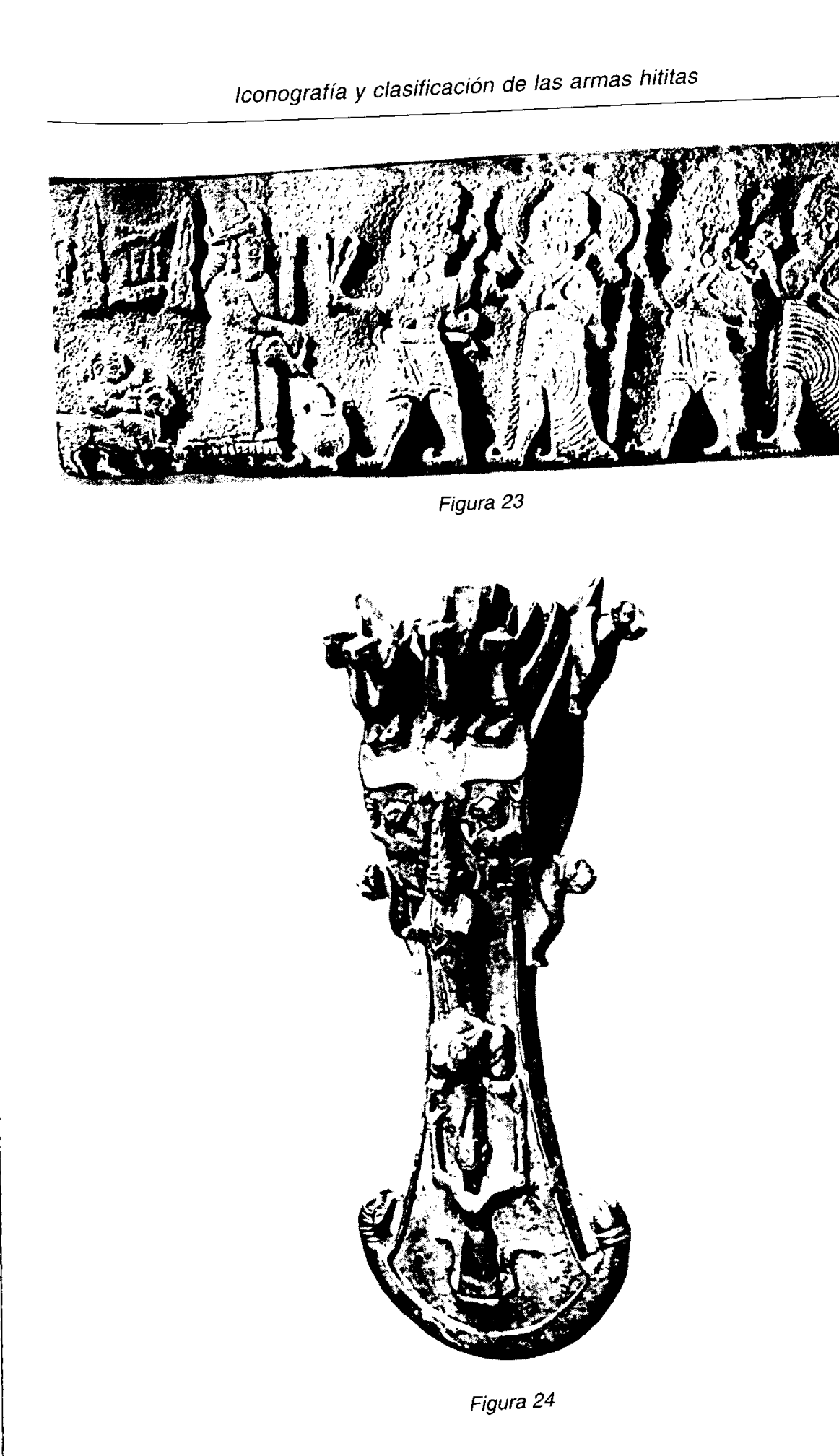


4.2.1.3. Bidentes. La figura de la derecha, mirando en ese sentido, porta en su mano izq. un enorme bidente curvado de más de $2 \mathrm{mts}$ de longitud. Arma sin duda altamente ofensiva y mortal de necesidad. Figura n. ${ }^{\circ} 25^{21}$, que podemos observar en la tablilla cuneiforme de barro cocido del S. XIX a.C. y que se encuentra en el MAA.

Probablemente el origen del bidente de la figura, como los tridentes y cuatridentes, se encuentra en los antiguos útiles campesinos para extender la hierba y aventar el grano.

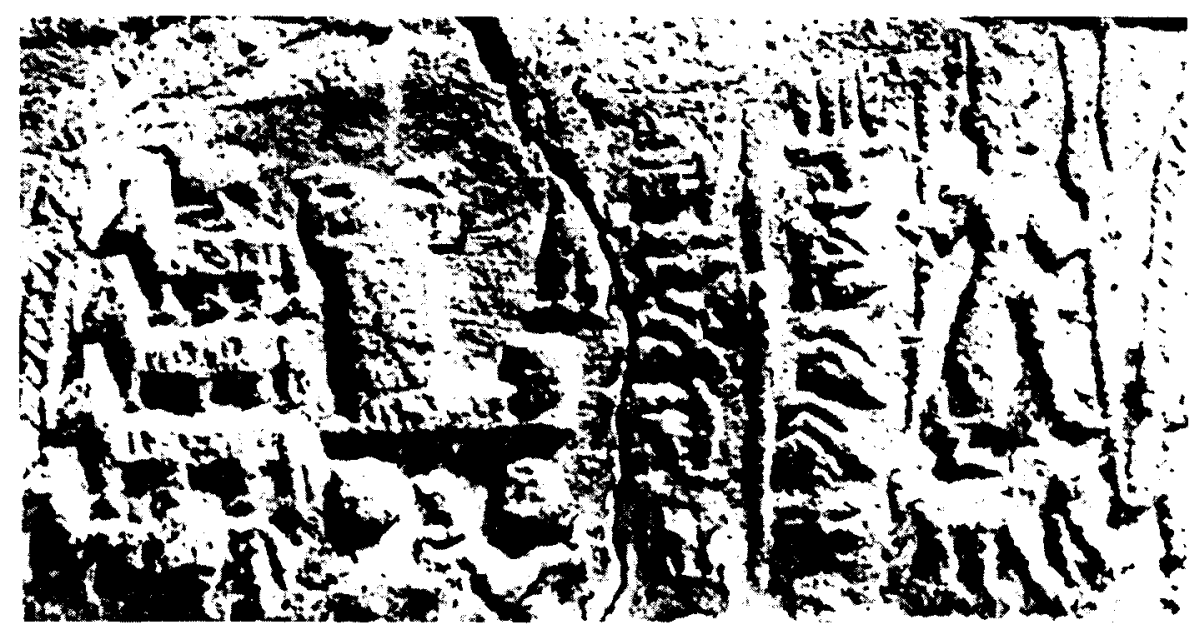

Figura 25

4.2.1.4. Mazas. Las mazas eran un arma mortífera de necesidad. Equivalente a un martillo, superaba increiblemente ese golpe. Sus tamaños y formas eran diversas. Así había mazas redondeadas, como la que aparece en la mano de Sethi I, en la fachada del templo de Amón en Karnak (figura $n .^{\circ} 26$ ), cilíndricas y ovoideas (como la que aparece en la paleta de Narmer ${ }^{22}$, figura ${ }^{\circ}{ }^{\circ} 27$ ).

En la figura $n .^{\circ} 28$, la figura de la izq. parece portar 2 mazas de distinta hechura: En su mano der. porta una maza sobre el hombro del mismo lado, con cuerpo cilindro-cónico, y en la izq. una gran maza ofensiva de 1,70 de longitud y terminada en su extremo distal en una cabeza de golpear ovoidea.

Tablilla cuneiforme de barro cocido del s. xIx a.C. Museo arqueológico de Ankara.

Que se puede contemplar en el museo de El Cairo. 


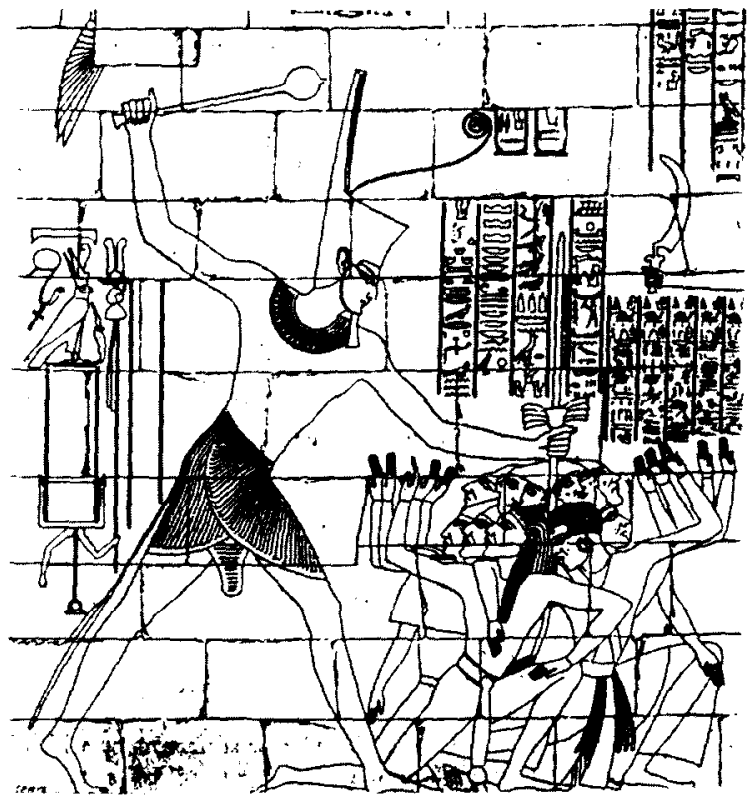

Figura 26

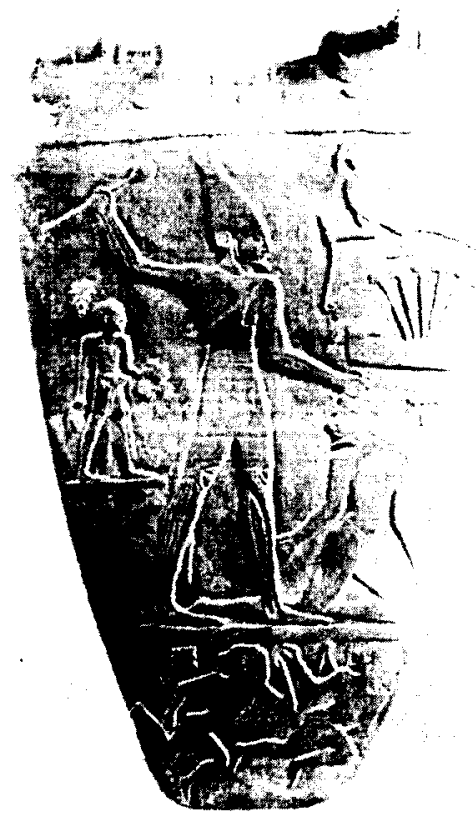

Figura 27 


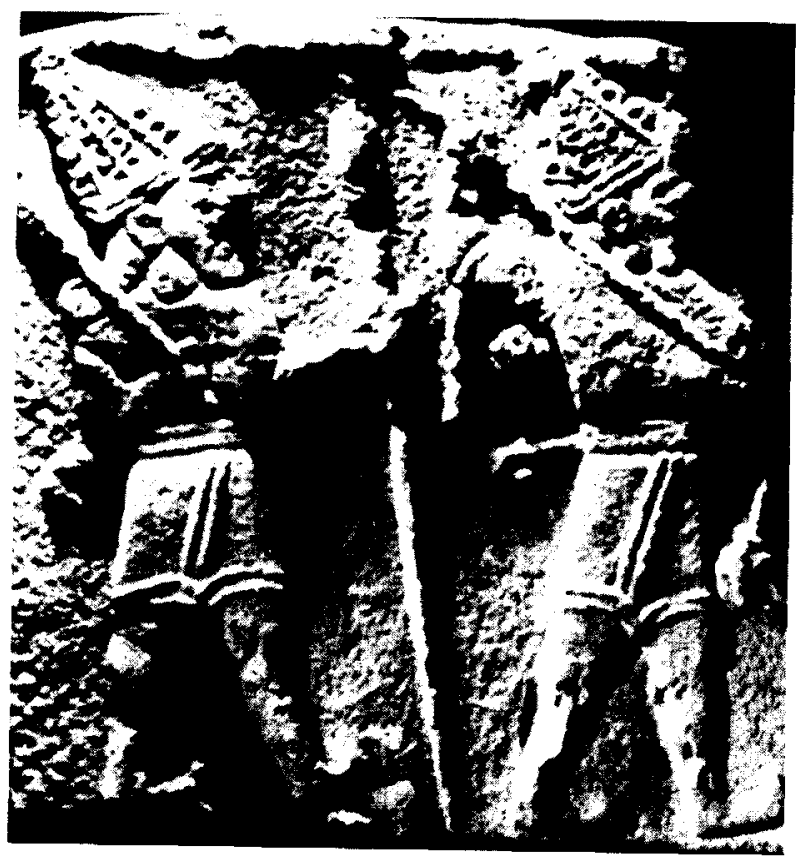

Figura 28

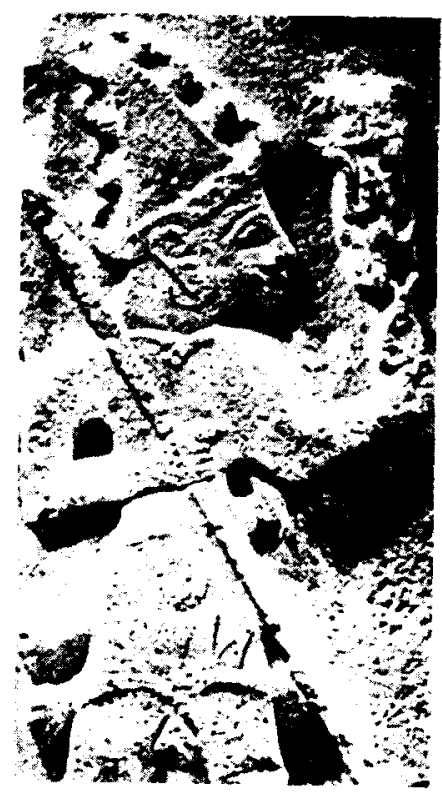

Figura 29 


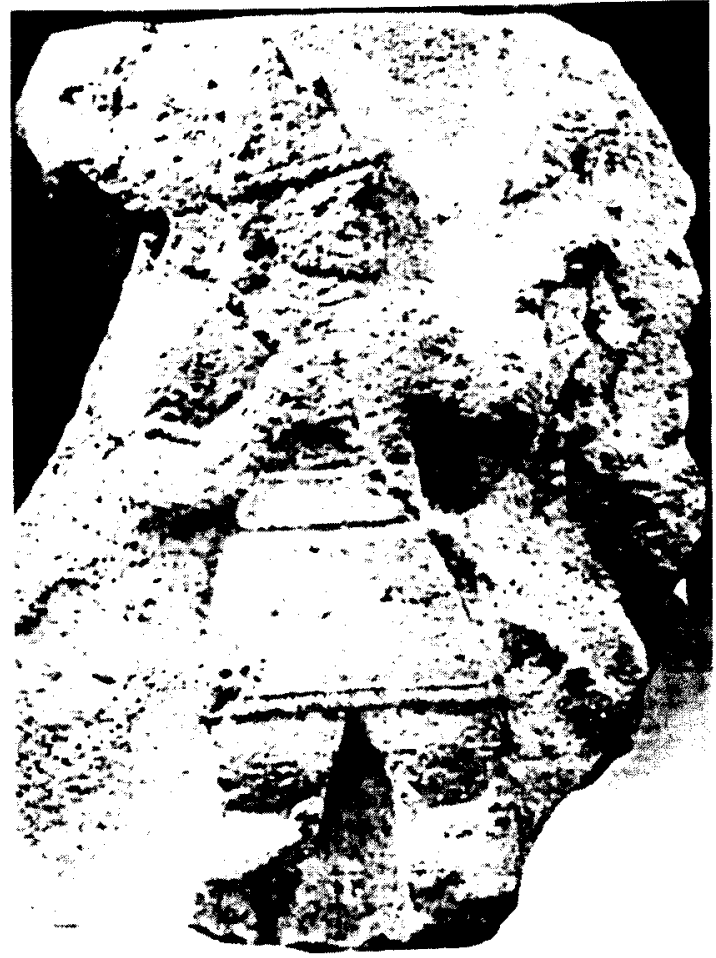

Figura 30

Las mazas estaban compuestas por un mango cilíndrico de madera, más o menos largo (en raras ocasiones de metal) y un cuerpo principal o maza, propiamente dicha, cuyo material era cobre, bronce o piedra, e incluso, en ocasiones, de madera, horadado por el centro longitudinal por donde se introducía fuertemente el mango. Las formas más comunes fueron esféricas, tronco-cónicas, ovoideas, cilíndricas y más raramente piramidales.

4.2.1.5. Venablos. Las figuras correspondientes a las figuras $n .{ }^{\circ} 29$ y 30 , portan venablos muy similares. La forma de lanzamiento que se aprecia en el lancero de la figura $n .^{\circ} 31^{23}$, nos ilustra sobre el modo de lanzarlo: asiéndolo fuertemente por su extremo distal con la mano y formando con la palma de la otra un modo de rampa de lanzamiento, para atinar el blanco. Las figuras parecen ser lanceros de infantería.

23 Fragmento de vaso de barro cocido pintado del s. XVHI a.C. Museo arqueológico de Ankara. 


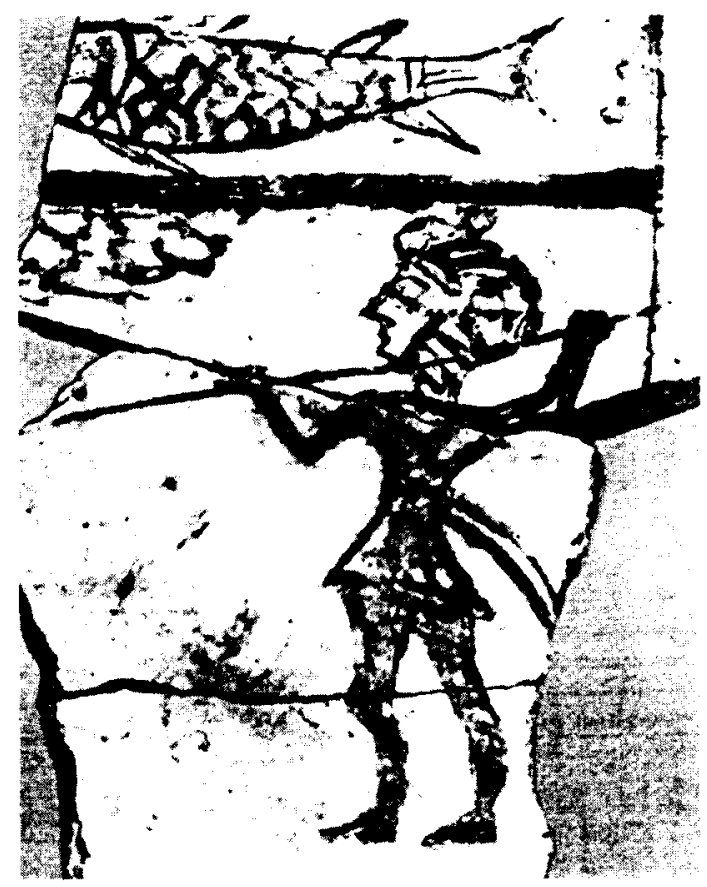

Figura 31

4.2.1.6. Arcos y flechas. Arma ofensiva de largo alcance que, en manos expertas, originaba gran mortandad en el enemigo. Si bien en sus formas más arcaicas constaba de dos cuernos de antílope unidos por una madera hueca central, hasta evolucionar con una lámina de madera y terminar con los arcos, más potentes en su alcance y certeza de tiro, de los forjados por diversas tiras laminadas de diversos materiales. En los planes de táctica militar era un cuerpo especializado que se utilizaba dentro de los primeros momentos de la batalla, así como en los carros de combate y antes del cuerpo a cuerpo que era un momento posterior de la batalla.

Con referencia a las flechas; es decir, sus puntas, ya que la varilla era de madera (desconocemos su clase), también se utilizaron, además del silex, el hueso afilado y el cobre, puntas de bronce fundido en moldes de arcilla por medio del sistema de "cera fundida".

Las figuras $n .{ }^{\circ} 32,33$ y 34 , nos muestran diversos arqueros hititas, unos en marcha con el arco destensado y portandolo en el hombro y otros en el momento de tensarlo y a punto de disparo. 


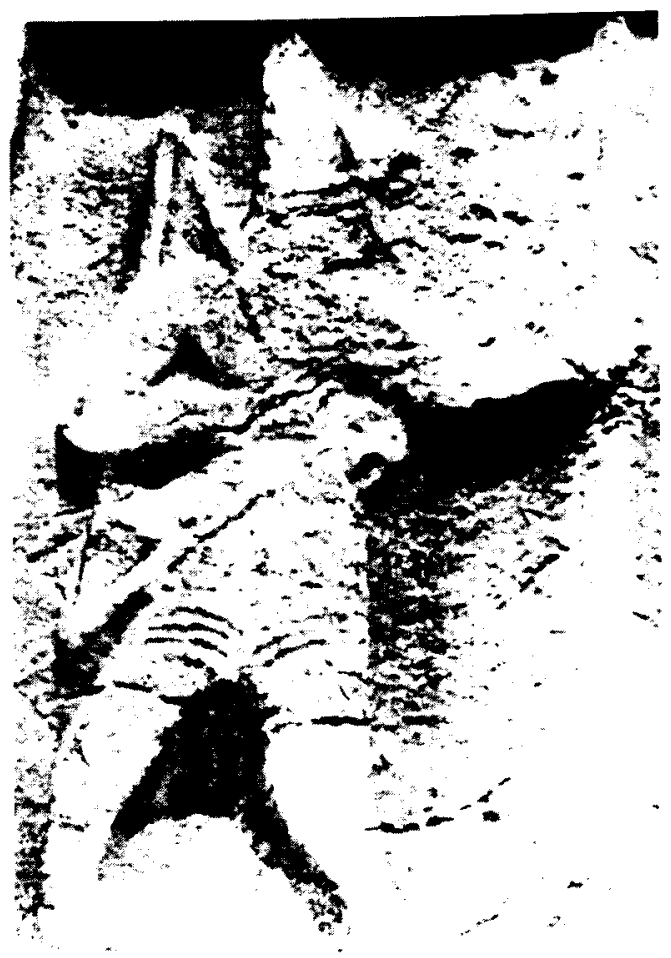

Figura 32

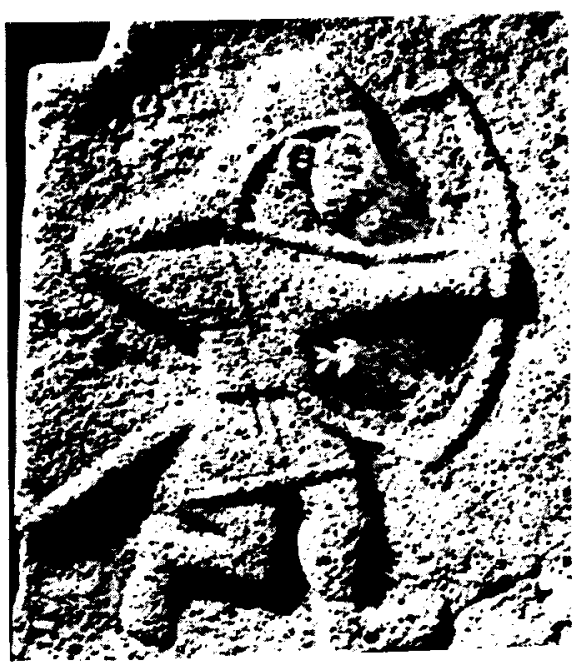

Figura 33 


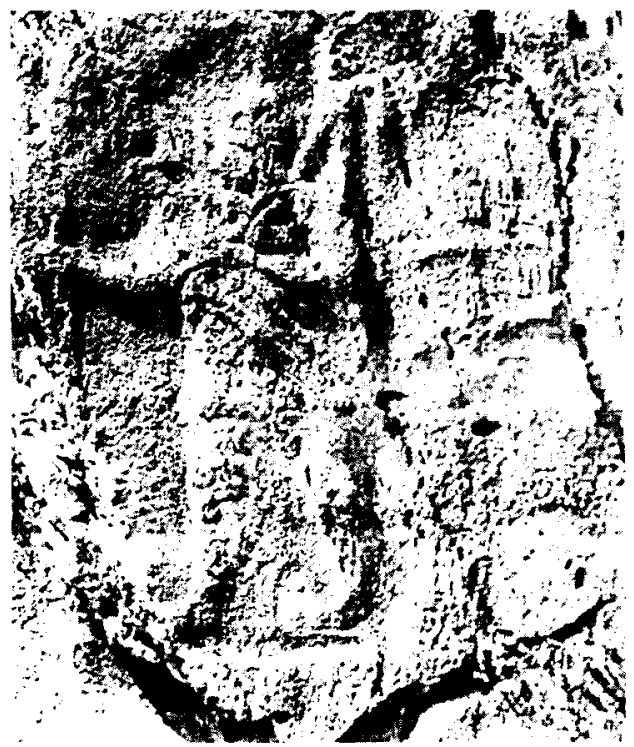

Figura 34

4.3. Defensivas. Fundamentalmente está el escudo, fuese redondo o de extremos semicirculares u ojivales, según algunos grabados y maquetas egipcias (figura $\left.n .^{\circ} 35\right)^{24}$, los cascos de diversa factura y forma, las armaduras y los petos.

4.3.1. Cascos. No es imposible que los jefes guerreros utilizaran, tanto cascos tipo "colmillo de jabali» como el que se aprecia en la figura n. ${ }^{\circ} 36$ como otros tipos que pasamos a describir: El casco presentaba mayores variedades, tanto en forma como en material. Mientras unos, a semejanza del posterior casco corintio, cubría toda la cabeza, occipital y pabellones auditivos, dificultando con ello la audición (figuras $10,15,18$ y 31), otros eran cónicos, probablemente de cuero $(13,16,17,30,32)$ y puede que algunos ceremoniales o, incluso, usados para la caza (figuras $n .^{\circ} 23,28,29,32$ ) y, por último, los semiesféricos metálicos $(11,33)$ los cuales dejaban al descubierto los oidos y las caras laterales del cuello y otros, semiesféricos, acabados en un vértice puntiagudo como el de la figura $n .^{\circ} 37$.

4.3.2. Escudos. Respecto al escudo hitita, si tomamos como ejemplo el muy posterior utilizado por los hoplitas griegos (el hoplan, como escudo re-

24 Maqueta encontrada en la tumba de Mesehti, en Asyut, de la XIl dinastía y que se encuentra en el Museo Egipcio de El Cairo. 


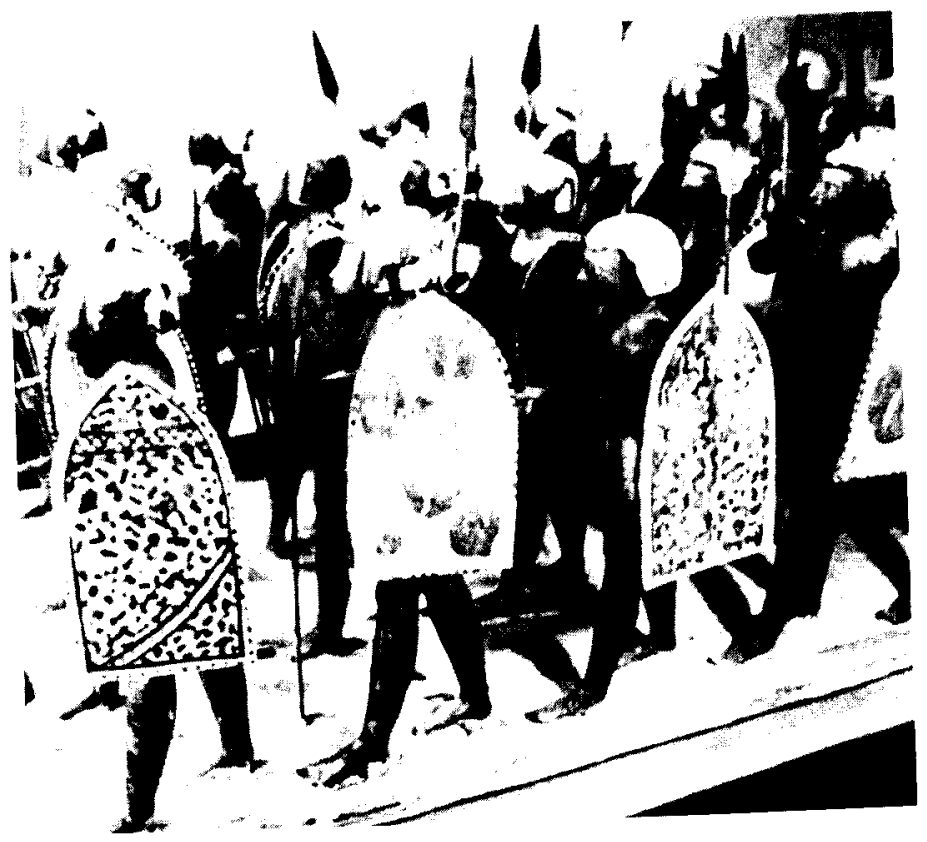

Figura 35

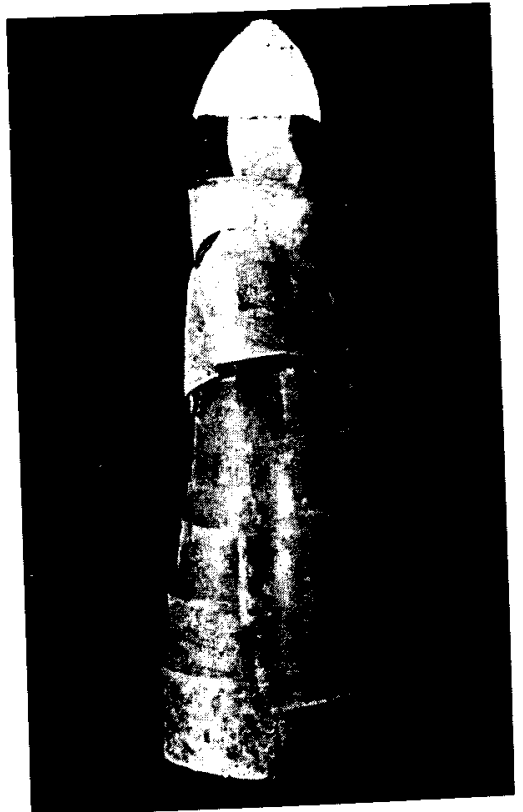

Figura 36 


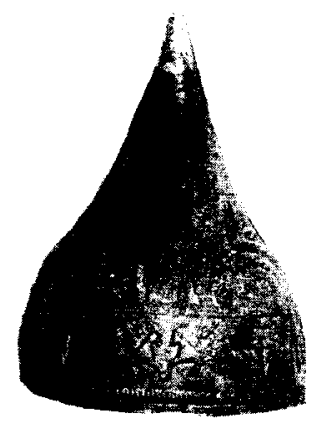

Figura 37

dondo, ligeramente curvo, y de casi $1 \mathrm{mt}$. de diámetro, hecho de madera y añadidos de bronce) que se sujetaba con una correa por la que pasaba el brazo y un asa periférica, excepto su tamaño más pequeño, no habria de diferenciarse mucho. Pero iconográficamente sólo tenemos los escudos redondos y más bien pequeños que asoman por la borda de sus barcos y los escasos relieves egipcios donde aparece la infantería hitita portando tanto escudos enormes de la altura de un hombre (figura 38), como otros menos grandes y con su extremo superior ojival, como los usados por la infantería egipcia (figura 35), otros, en fin, más llevaderos y rectangulares, cuyos extremos distales forman una hendidura semicircular, tal y como se puede comprobar en el relieve de la batalla de Qadesh en las orillas del rio Orontes y que se encuentra representada en la pared derecha del atrio del templo de Ramsés II en Abu Simbel, por el artista que la grabó, Hui (figura $n .{ }^{\circ} 39$ ). $Y$ cuyo detalle donde se aprecian tales escudos hititas, es la figura $n .^{\circ} 40$.

4.3.3. Armaduras. La armadura (figura $n .^{\circ} 36$ ), como protectora del cuerpo, si nos guiamos tanto por el antes citado cuerpo de élite griego, como por los soldados egipcios coetáneos a los hititas, no era, precisamente, muy común, y mientras una mayoría iría a pecho descubierto (figura 35 y 38), e incluso semidesnudos, otros se cubrian con un peto ligero de cuero curtido o cobre batido para proteger el torax, y una placa dorsal, uniendo ambos por un correaje a los costados. Un ejemplo griego, lo tenemos en la figura $n .^{\circ} 41$, donde se aprecia la coraza y el yelmo de bronce laminado hallados en una tumba de Argos de finales del S. VIII a.C.

\section{LA CABALLERIA}

Si bien el caballo, como animal de tiro, ya era conocido en la Anatolia ocupada por los hititas, y con otros pueblos del Asia Menor (no hay más 


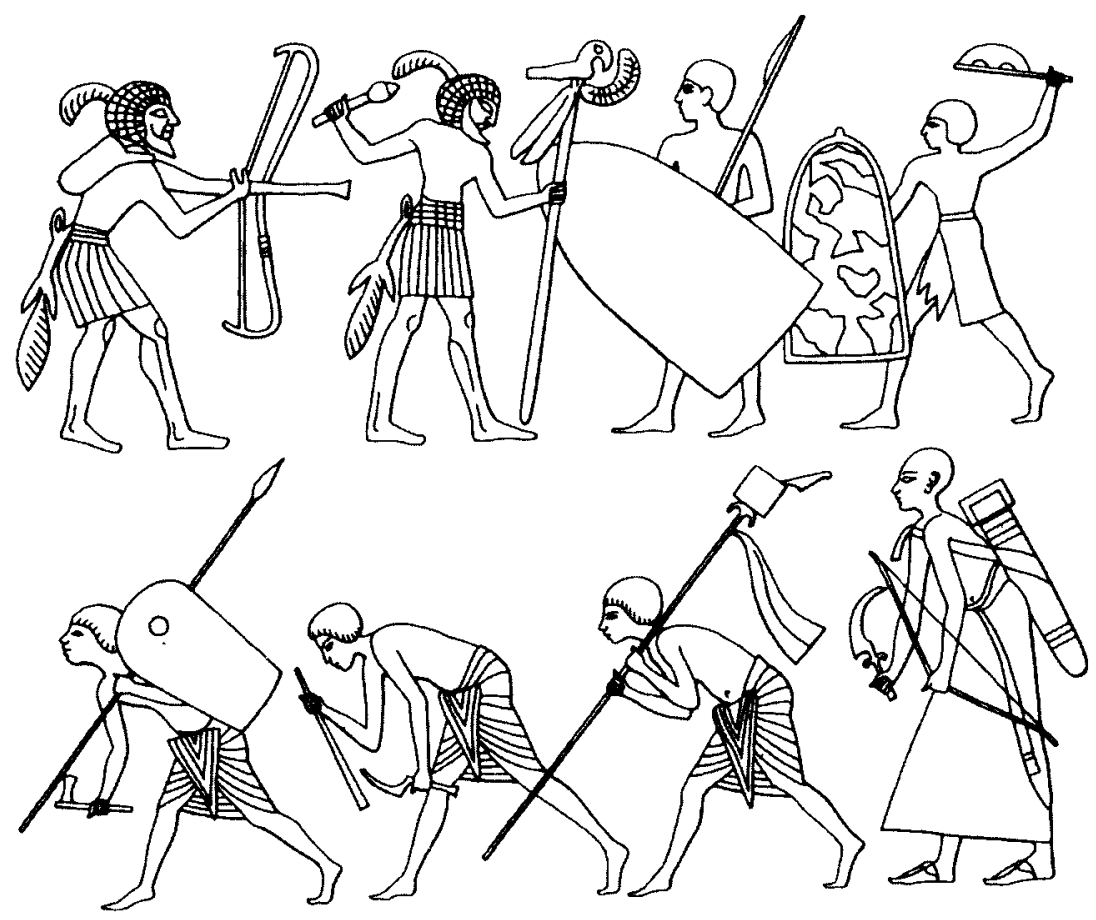

Figura 38

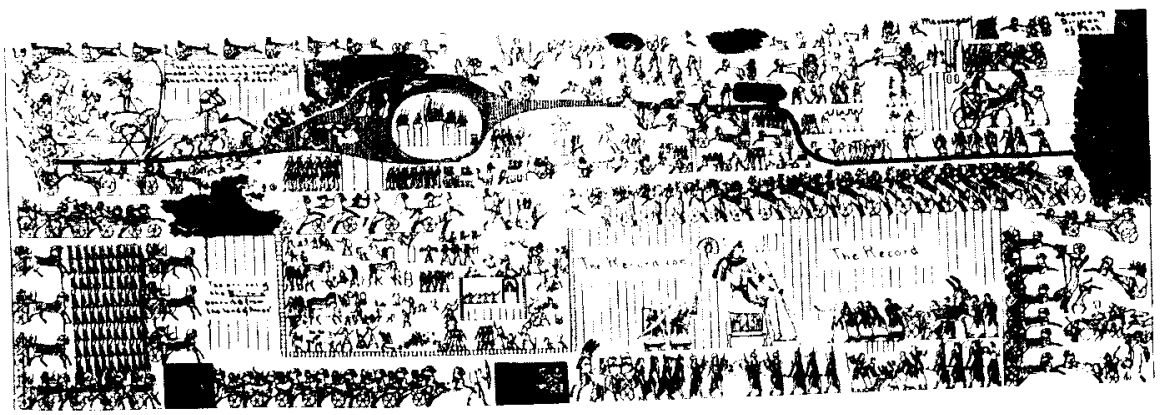

Figura 39 


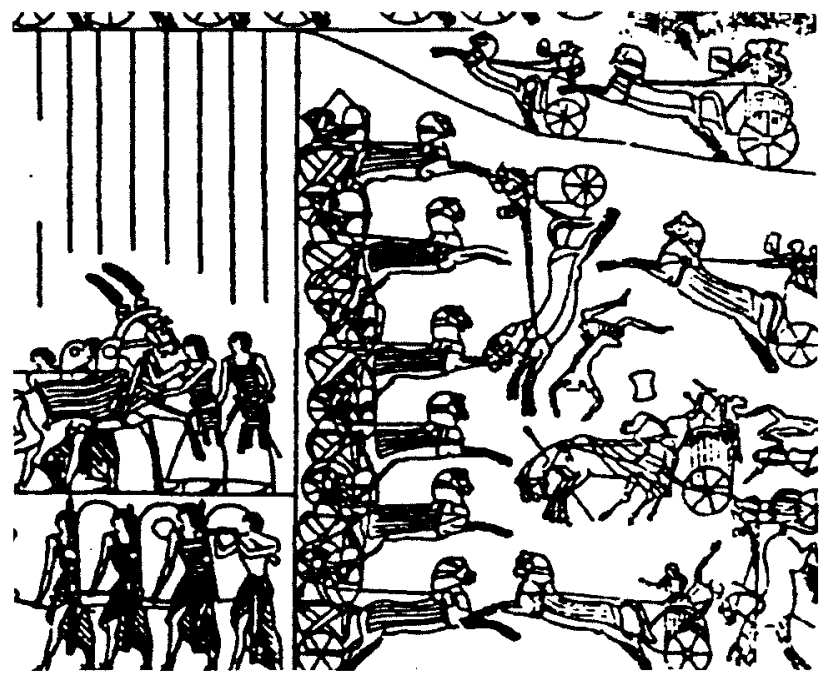

Figura 40

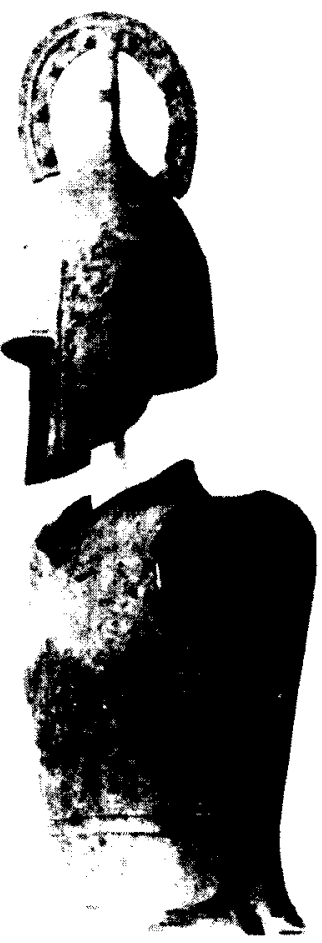

Figura 41 
que recordar el "tratado de hipología" de Kikkuli) y utilizado en el transporte pesado y comercial, llevando pesados carros de grandes cajas y ruedas macizas, hay que reconocer a los hititas la innovación de transformar el pesado carro, tirado por varios caballos, asnos o bueyes, por el ligero y de pequeña caja, tirado por un solo caballo. Esa transformación tan fundamental originó la aparición en el ejército del "carro ligero de combate» en el que eran transportados dos o tres ocupantes: el conductor o auriga, el arquero o lancero y el escudero o protector.

Sin embargo, como he dicho más arriba, desconocemos casi todo sobre la cuestión, dada la escasa iconografía que nos ha llegado o de los relatos fragmentados que conocemos. Suponemos que la caballería (figura $n .{ }^{\circ} 42$ ) era un cuerpo de élite y que, probablemente sería un cuerpo militar profesionalizado, e incluso, noble o aristócrata.

Su importancia era tan fundamental que hay textos hipiátricos hititas (y acadios) dedicados al entrenamiento y enfermedades de caballos, con un conocimiento exhaustivo sobre esos animales dedicados a preparar los para arrastrar los famosos carros ligeros de guerra hititas ${ }^{25}$.

Las armas de la caballería eran el arco y la espada si nos guiamos por el relieve del palacio de Kalhu (figura $n .^{\circ} 43$ ).

Incluso Marti-Brugueras ${ }^{26}$ cree que el coste del carro y el sustento del caballo corría a cargo de tales poderosos. Sin embargo en realidad esto es pura conjetura.

7.1. Carros. Podemos distinguir los ligeros o de ataque, que eran la élite del ejército hitita (aún cuando ellos no fueran los inventores), con ruedas de radios (figura 44), elementos fundamentales en la batalla por su versatilidad rodeando con un cerco al enemigo, y los pesados de rueda maciza y un gran cajón de carga, tirados por asnos, incluso en ocasiones arrastrados por bueyes y que transportaban los pertrechos de guerra, intendencia e incluso traslado de enfermos, heridos y familiares de los contendientes (figuras 45,46 ). Si analizamos la figura 47 , podemos inferir la existencia de "carros-arietes", es decir un enorme tronco ahuecado, con ruedas y que lleva un grupo de arqueros con lórigas acorazadas. Probablemente el carro-ariete era enfocado a la puerta de la ciudad y dirigido contra ella, al objeto de derribarla, mientras los arqueros disparaban

25 Para los interesados vid. Oppenheim. A.L. Glass and Glassmaking in Ancient Mesopotamia. New York 1970. Y del mismo autor: "Man and Nature in Mesopotamian Civilization". Dictionary of Scientific Biography XV. New York, 1978.

26 Vid. bibliografía no exhaustiva: "Los Hititas", pág. 164 


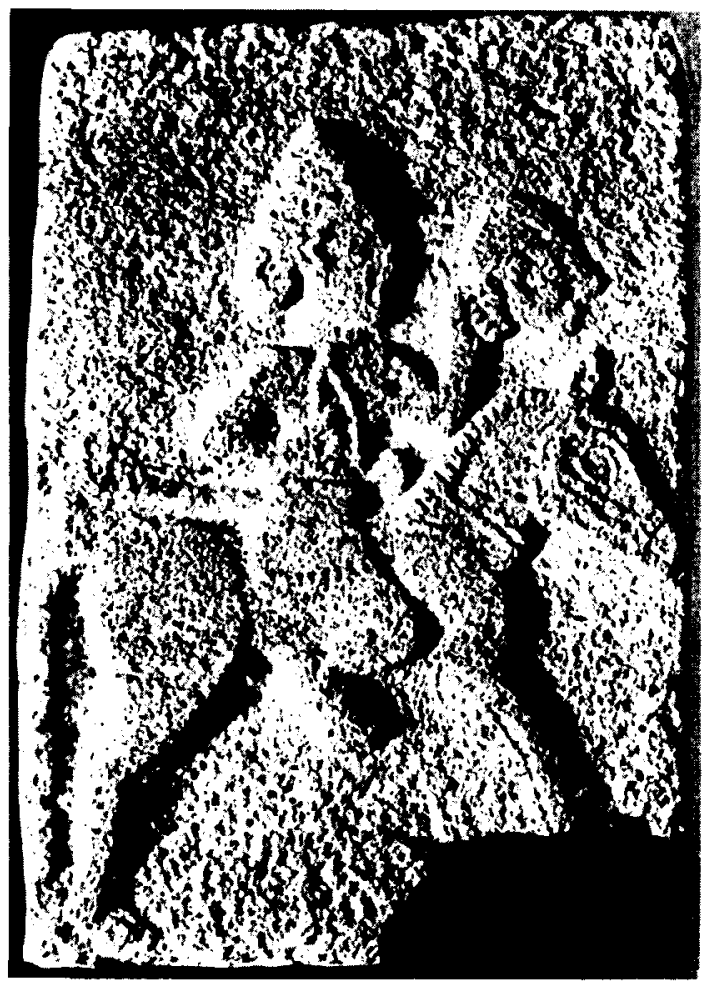

Figura 42

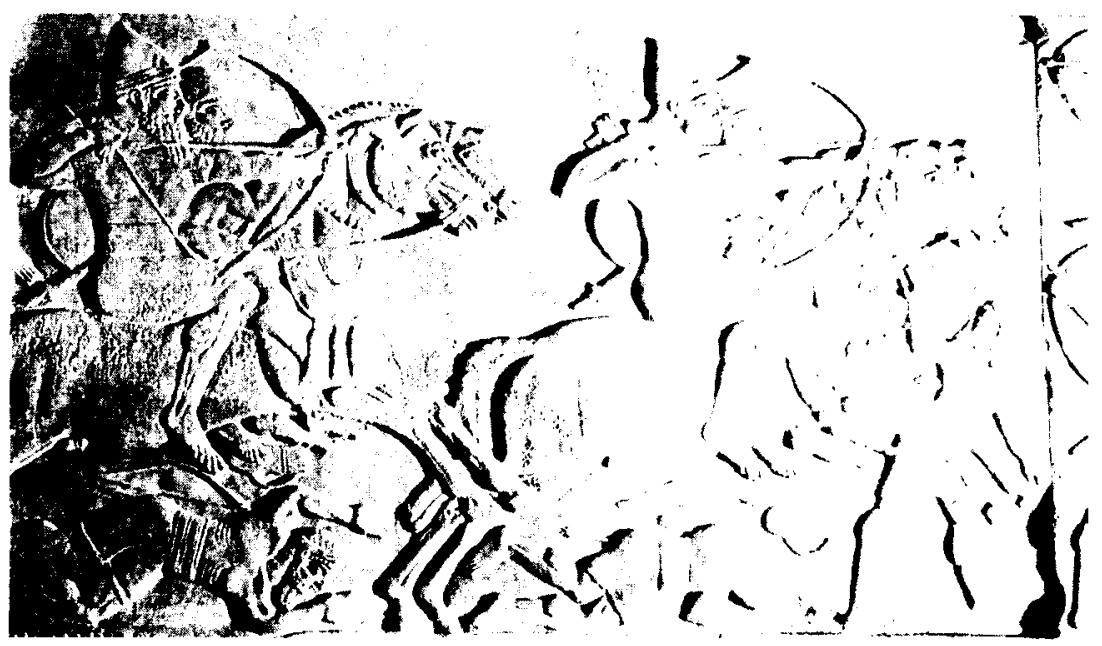

Figura 43 


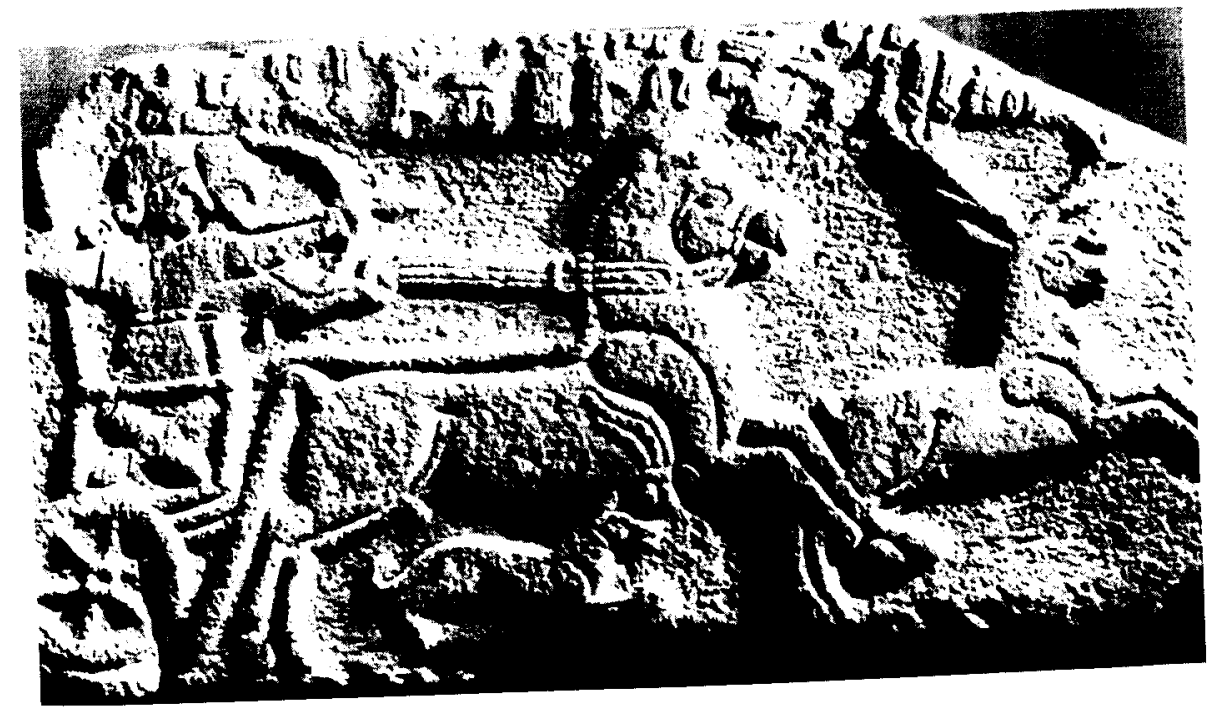

Figura 44

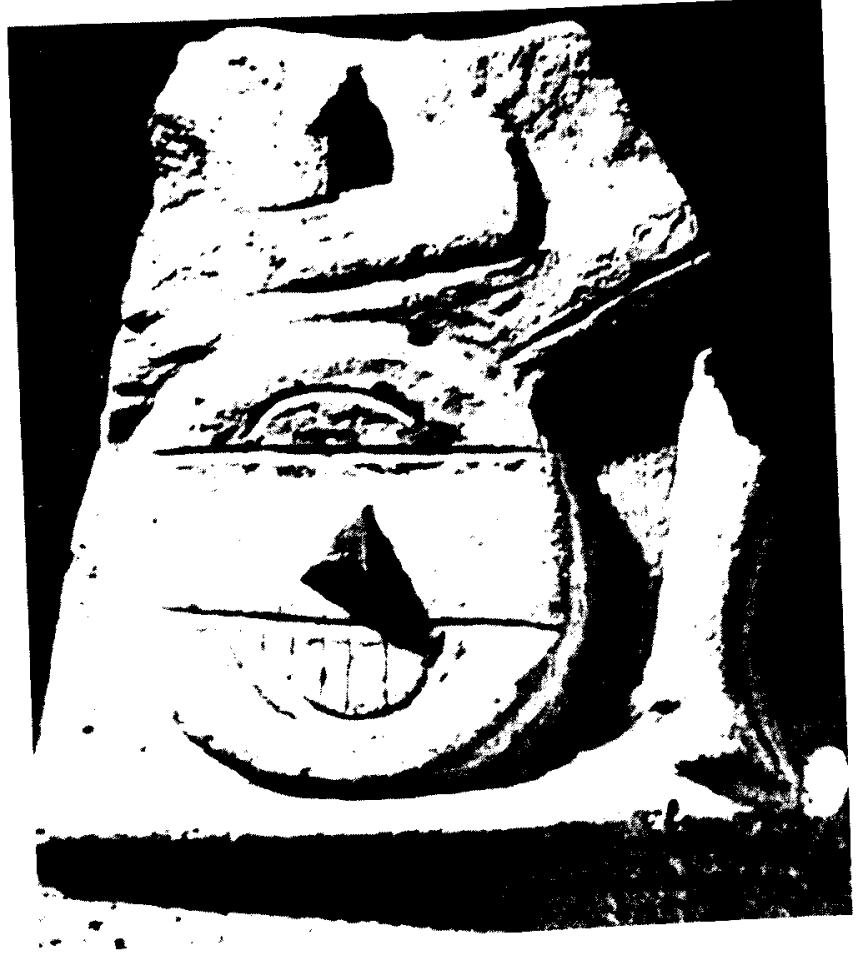

Figura 45 


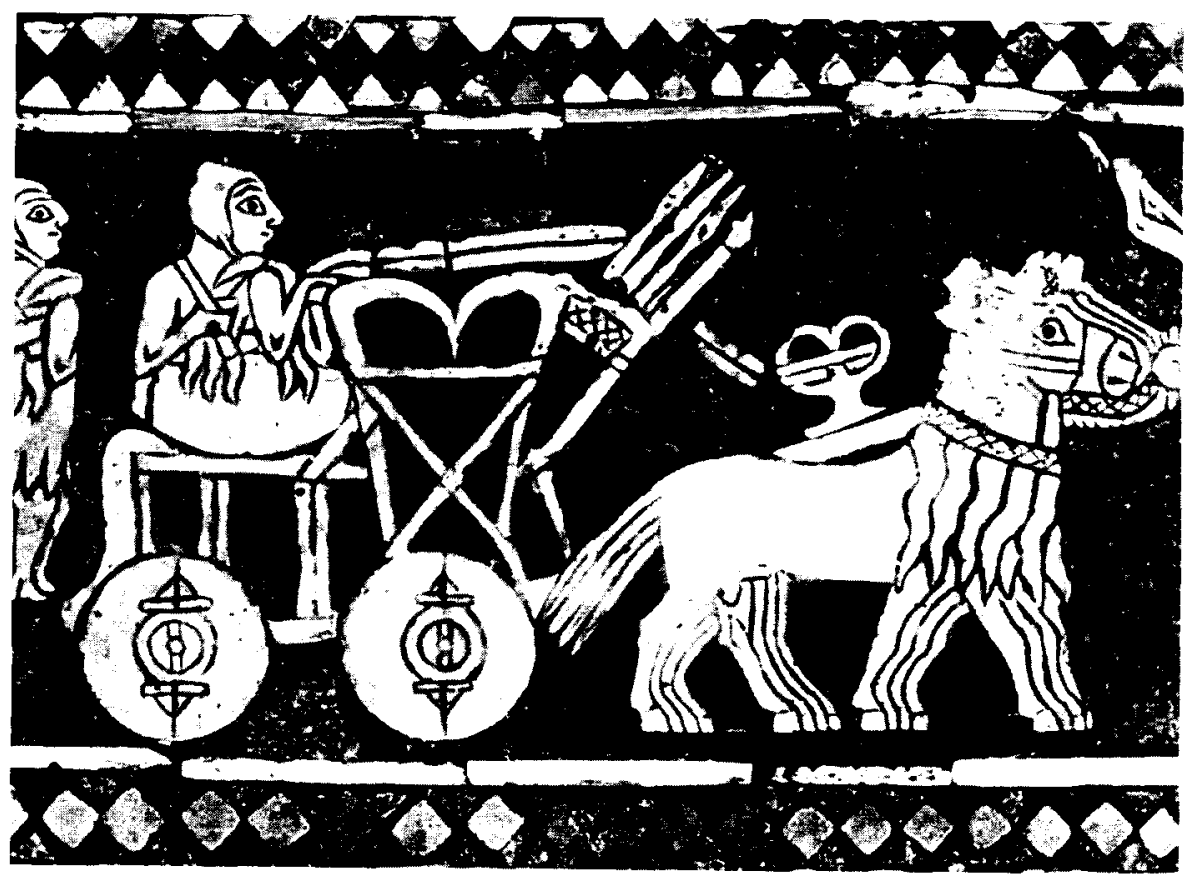

Figura 46

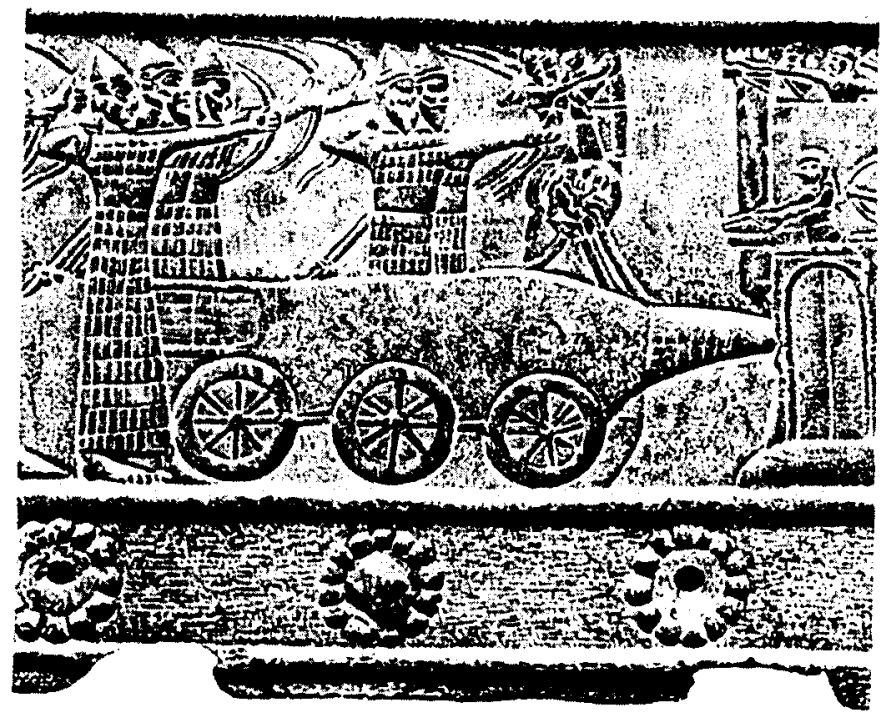

Figura 47 
sus flechas contra quienes estuviesen en lo alto de las murallas y almenas, tal y como se desprende del pasaje que refleja el grabado.

Junto a ellos cabe distinguir, más por su función de utilidad temporal que por su utilización formal, entre carros de caza y carros ceremoniales.

Los carros ligeros de guerra arrastrados por 2 ruedas están documentados tanto en la tumba de Tut-Ankh-Amón /1352/1344 a.C.), como en la batalla de Qadesh entre Ramsés II y Muwattallis II (circa 1.285 a.C.). Vehículos sumamente ligeros, cuyas ruedas eran de radios construídos con gubias y escoplos de bronce, y cuya madera era doblada por la técnica del calor. Todos los ensamblajes se hacían atenazándolos con correas de cuero cuyo entramado se utilizaba para el piso del carro, y que los griegos también utilizarán despues (figura 48).

Los carros de combate llevaban, además del conductor o auriga, dos arqueros y su misión fundamental consistía en deshacer en el primer choque a la infantería enemiga. Además de veloz plataforma de los combatientes (figura 49) ${ }^{27}$.

La iconografía del carro de guerra nos enseña gráciles ruedas de 6 y 8 radios (figuras $50,51^{28}$ y 52 ), en contraposición a las macizas y pesadas ruedas del carretaje sumerio (figura $n .^{\circ} 45$ y 46 ) que aparece en el estandarte de Ur (2.600/2.400 a.C.)

Pero los carros de combate se expanden con rapidez entre los diversos pueblos antiguos en los siglos XIII a XI a.C. y acaban siendo un protagonista principal en las guerras del mundo antiguo (figura 53), si bien los hititas parecen haber sido altamente especializados en ellos y su utilización bélica.

Una cuestión perpleja sobre la antigüedad y expansión lejana de los carros de combate en zonas tan alejadas de Hatti como el Tasili, el Ahaggar, el sur de Marruecos o la Mauritania, (Sahara), son los documentos pictóricos descubiertos en Tin Abú Teka y en Ala-n-Edument (figura n. ${ }^{\circ} 54$ y $55)$ donde se ven carros de estilo micénico. Las pretensiones de que se trate de pinturas de época romana, ser carros cirquenses y que incluso jamás circularon por el Sahara, no pueden ya sostenerse. El contexto de las pinturas acredita que se encuentran en los estadíos de los bovidienses y del caballo y, por tanto, muy anteriores a la época romana. Fue, pues, empleado como carro de caza y de guerra por las antiguas poblaciones del Sahara, como asi lo atestiguan tanto las crónicas egipcias de la XVIII dinastía, como los autores antiguos griegos y romanos.

${ }_{27}$ En este ortostato de basalto, en relieve, que se encuentra en Staatliche Museen, de Berlin,

arkemish, del s. Ix a.C. que se encuentra en el MAA 


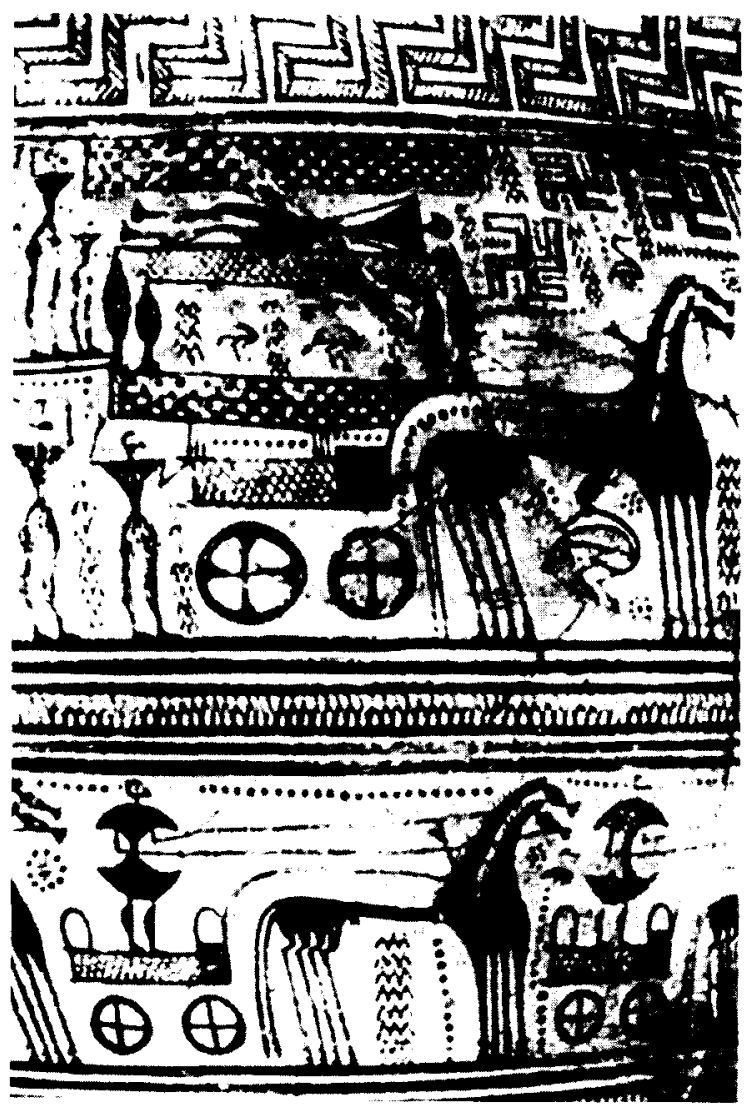

Figura 48
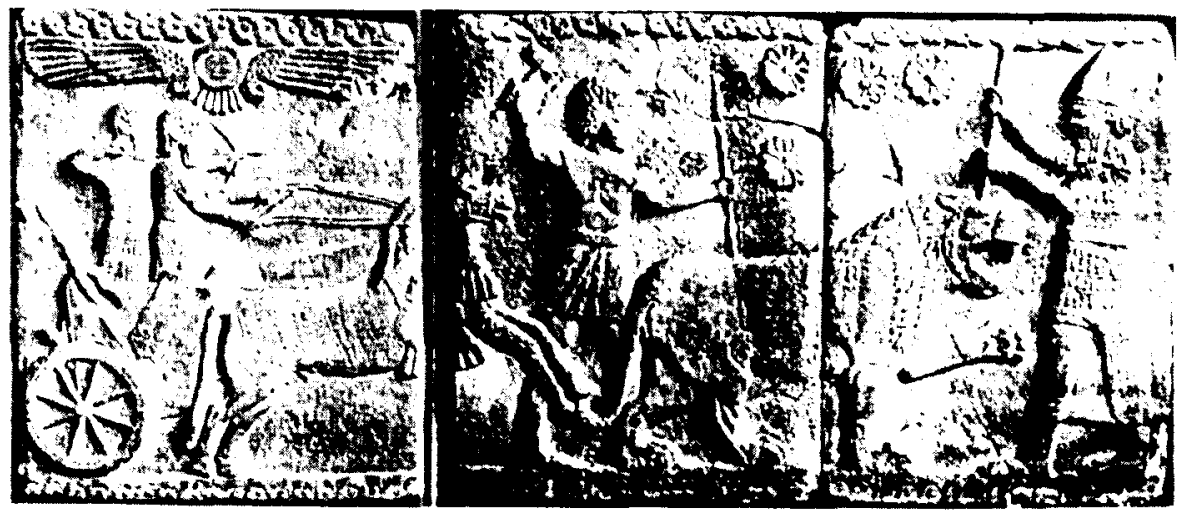

Figura 49 


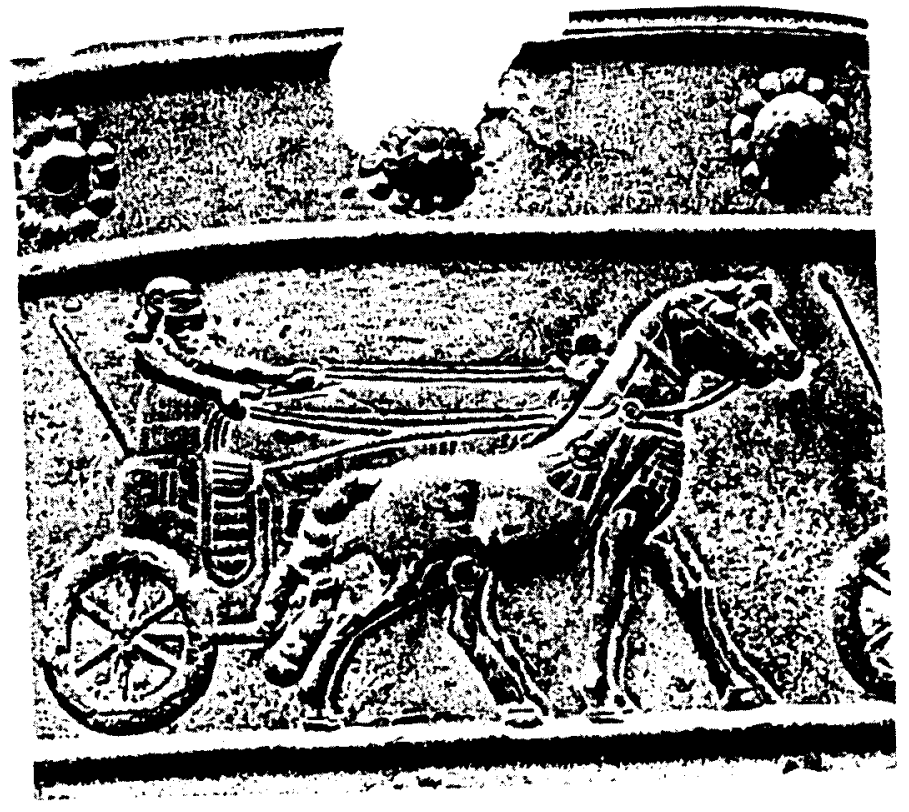

Figura 50

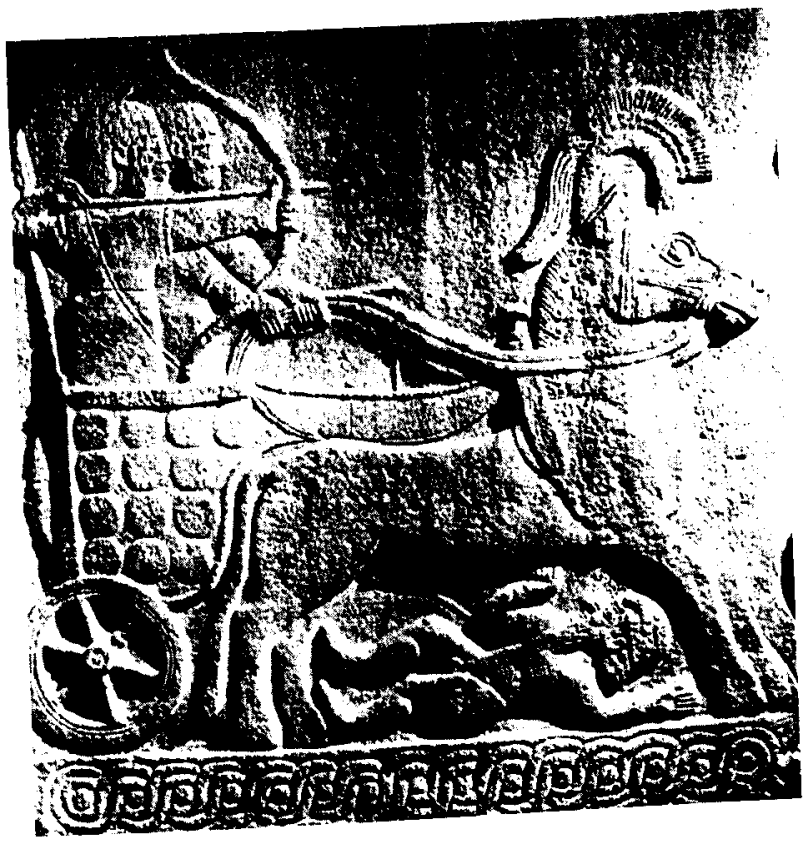

Figura 51 


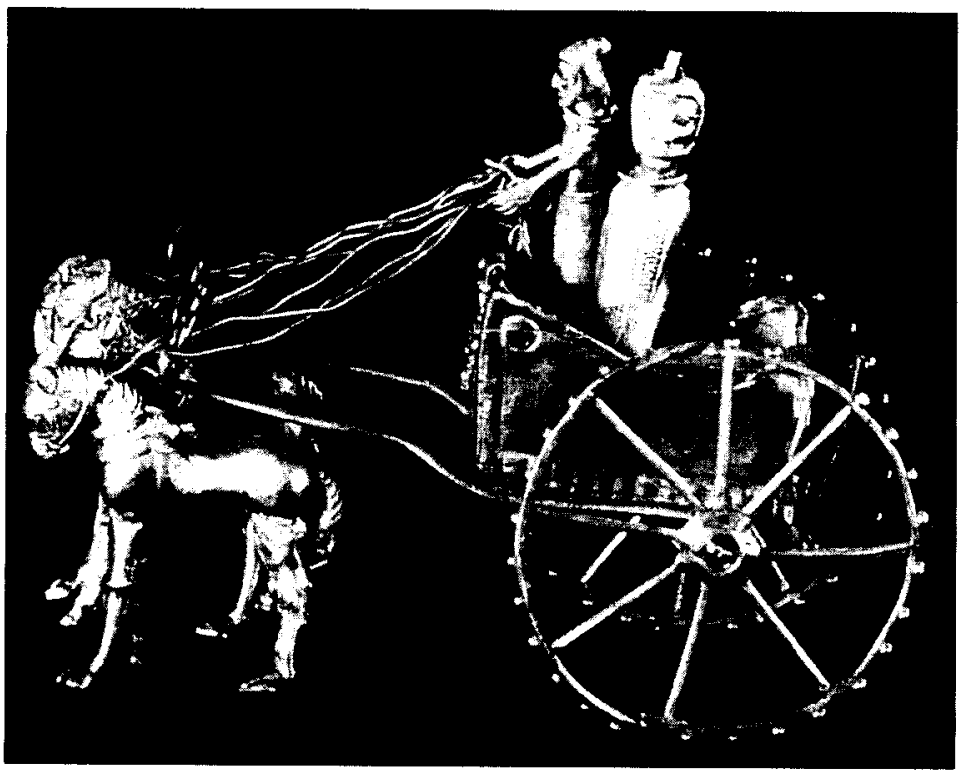

Figura 52
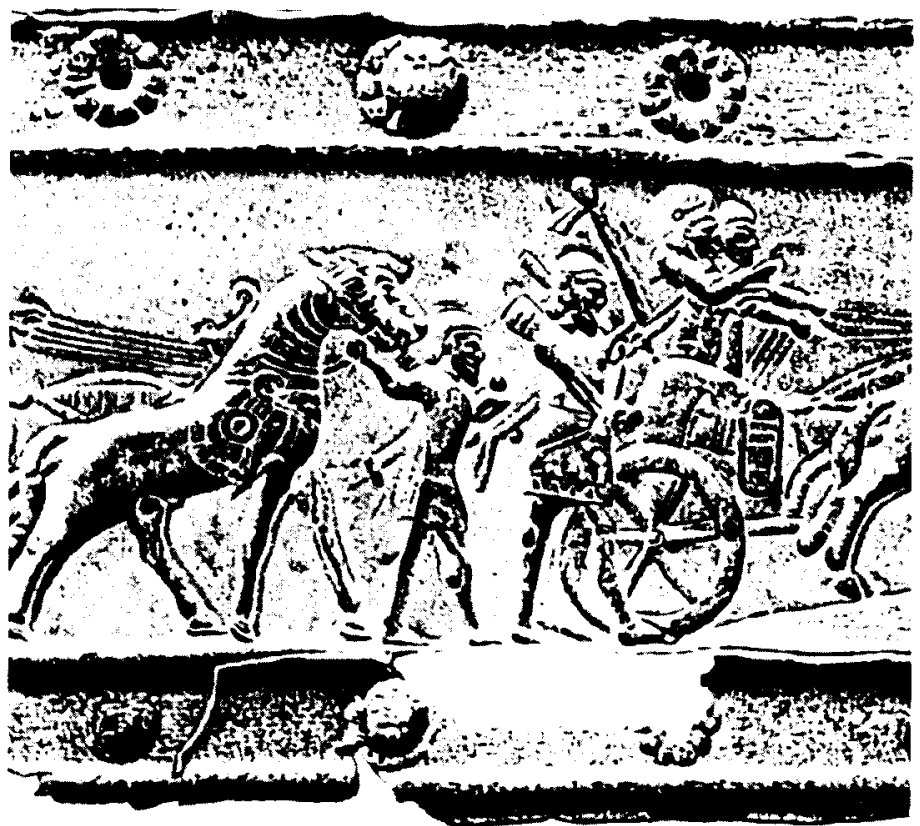

Figura 53 


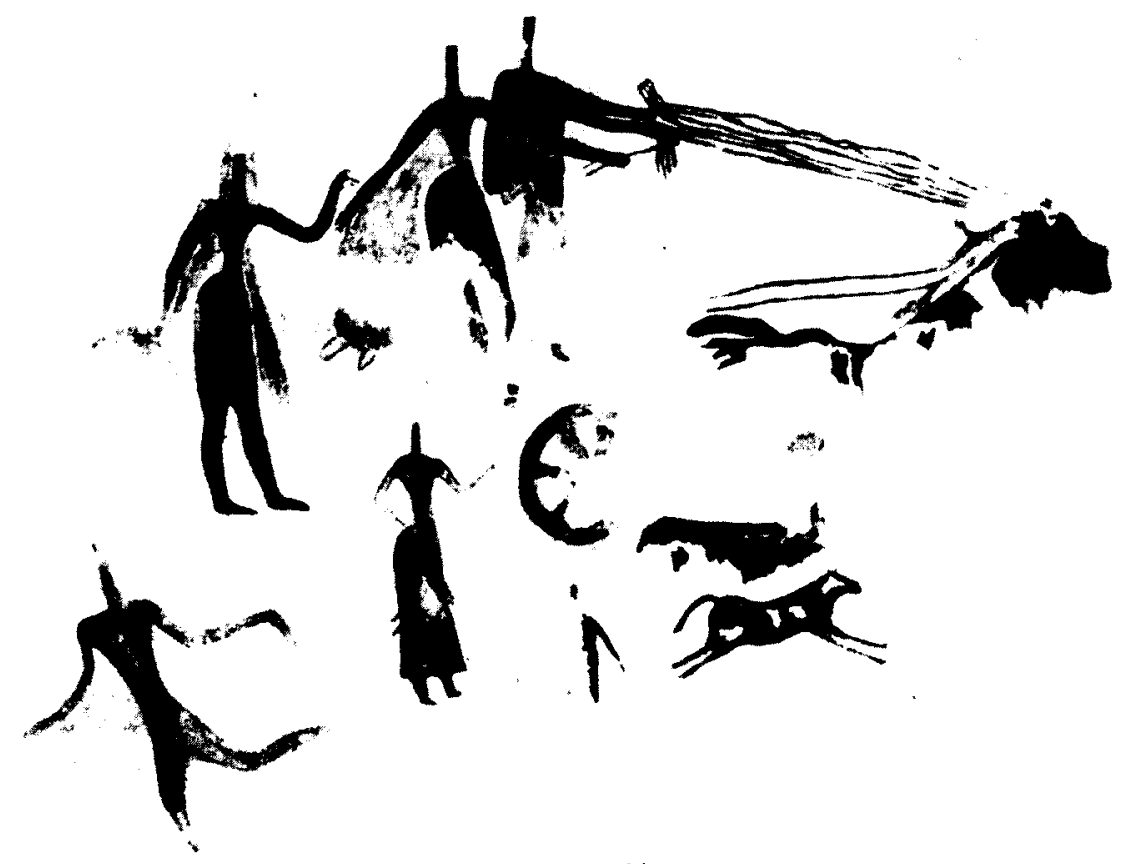

Figura 54

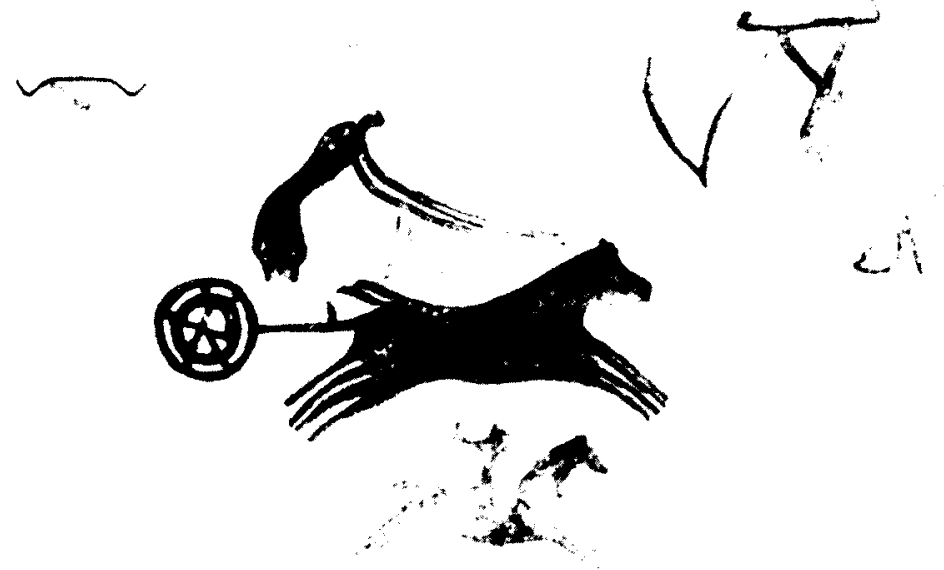

Figura 55 


\section{LA INFANTERIA}

Era el cuerpo militar más numeroso y también el más heterogéneo. Tropas de élite, otras puntuales formadas por artesanos, agricultores y ganaderos y otras auxiliares compuestas por las levas llevadas a cabo como préstamo de paises vasallos o con los que se mantenían pactos y lazos de reciprocidad tras tratados de mutua ayuda, e incluso tropas mercenarias, como el caso de los "apiru" ${ }^{29}$ que se citan en un fragmento de una crónica sobre Mursili I, cuando se lee: «reuní 3.000 apiru y los servidores de tropa ... y los dejé como guarnición", como consecuencia de las cruentas batallas mantenidas con los hurritas y los reinos de Arzawa y Alepo. Cavaignac ${ }^{30}$ identifica a los apiru con los hebreos. En muchas ocasiones las armas que portaban eran útiles empleados en su vida cotidiana: hoces con dientes de silex, hachas de piedra o cobre endurecido, venablos con mango de madera con punta endurecida por el fuego, o formada por silex o puntas de cobre, arcos de madera y cordada de cuero o tripa trenzada de caballo, mazas de madera o de piedra.

Junto a esas armas, digamos no profesionales, se encontraban las construidas para el ejército profesional, tal y como podemos ver en las figuras $n .{ }^{\circ} 35,38$ y $56{ }^{31}$, tanto egipcias como asiáticas.

En el "acta del proceso contra GALdU ${ }^{32}$ " se dice que la reina le habia entregado a éste, carros, utensilios de bronce y cobre, vestidos, telas, arcos, flechas, escudos, mazas.... Una serie de testigos también dicen que ni han cambiado ni tomado nada para ellos; así, carros, ruedas, carros ligeros de dos ruedas, plata, oro, escudos, mazas, arcos, flechas, infiernillos, cacharros de bronce, destrales, hachas, espadas de bronce....

\section{LA MARINA}

Sabemos muy poco, con certeza, sobre la marina hitita, pero sin duda el transporte marítimo está escasa pero debidamente documentado por

\footnotetext{
29 Para los egipios 3perw, nombrados en numerosos documentos donde los escribas los describen como bandidos o saqueadores (sa.gaz). En el siglo $\times x$ a.C. estaban en la Capadocia, en el xvill a.C. en Elam y en Mesopotamia y en el xV a.C. Amenhetap II los hace prisioneros en Canaán. Más tarde los veremos en Amarna.

30 Cavaignac, E; Grelot, P. y Briend, J. Les Hapiru. Introduction critique à l'Ancien Testament. Paris, 1973.

31 Se encuentra en el Museo Egipcio de Berlín.

3. GURNEY, HAASE y WERNER fueron traductores. En nuestro pais lo ha vertido al castellano. Bernabé y Álvarez-Pedrosa. Vid Bibliografía no exhaustiva.
} 


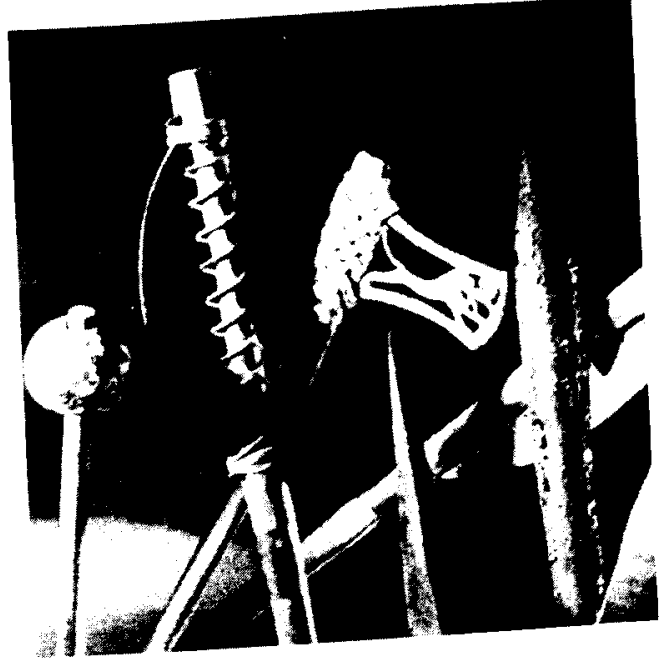

Figura 56

fuentes escritas. Navíos de más o menos calado, de cabotaje y navegación fluvial, nos han llegado ejemplos indiscutibles. El oficio de la piratería, casi tan viejo como el mundo histórico, sería otro de las efectos de la navegación.

9.1. Barcos. No cabe duda de que el imperio Hitita, como otros pueblos de la antigüedad, con intereses comerciales y estratégicos, poseyó bien una flota propia, bien fuese prestada por reinos costeros vasallos o bien arrendada, tanto para el transporte de mercaderías, como a como mo de guerra. Ello no quiere decir que su flota fuese tan poderosa como la micénica, por ejemplo. Como dice Cunchillos ${ }^{33}$ "Hasta su destucción Ugarit, que junto a Gubla, es el centro cultural y comercial más imporante, quedará del lado hitita. Será la que se encargue de darle al Gran Rey de Hatti poderío marítimo». De modo que, como decimos, Hatti dispone de una flota vasalla que se encuentra allende el mar, cuando en re otras cosas, tas lo api?) se dirige angustiosamente al de Alasiya y, entre olras cosas, tras los saludos de rigor se queja de "los pueblos del mar": "Padre han hecho nada do barcos del enemigo. Han quemado mis ciudades y no han fórmula de bueno en el país. Mi padre (se refiere al rey de Alasis de Hatti y que todos respeto) no sabe que todas mis tropas están en el pais d

33 Cunchillos, J.L. y Zamora, J.A. Gramática Ugaritica Elemental. Edic. Clásicas. Madrid, 1995. 
mis barcos están en el país de Lukka. Hasta el momento no han regresado y el país está abandonado a su suerte. Sepa mi padre estas noticias: Han llegado 7 barcos del enemigo y nos han causado muchas desgracias." ${ }^{34}$. Todo lo cual confirma nuestra suposición documental de la existencia de una flota hitita, fuese propia, vasalla o arrendada.

El arrendamiento de barcos está documentado desde el año 4 del reinado de ${ }^{\wedge}$ Su-suen de la III ${ }^{a}$ dinastía de Ur según la traducción de un texto procedente de Umma que hace Manuel Molina ${ }^{35}$ : "Atu le entregó a Ata un barco en alquiler. Lu-duga fue avalista. Halla y Da'aga fueron los testigos del alquiler del barco.». No importa que este documento fuese suscrito en Sumer. A este tipo de transacciones comerciales no eran ajenos los hititas. En cuanto a los barcos de transporte, y los dedicados a la guerra y a la pirateria, no tenian que ser, necesariamente distintos.

Al margen de todo ello nos quedan ejemplos y representaciones de barcos largos y, aparentemente, ligeros, de alto codaste y proa baja y roma, rematada en un sobresaliente espolón que bien podía tener 2 primordiales funciones, tales como la de sonda en aguas poco profundas y ariete en batallas navales, aún cuando realmente hay quien asegura que era al revés. Es decir, más alta la proa y la popa baja con un timón fijo.

Respecto a la propulsión se realizó primero a remo y más tarde a vela, cuya acreditación son los mástiles.

Dos, fundamentalmente, parecen ser los modelos de navíos más utilizados según podemos apreciar en éste dibujo de una batalla naval procedente de un mural del palacio de Senaquerib en Nínive, con ejemplos de barcos fenicios (figura $n .^{\circ} 57$ ). Los más cercanos a nosotros, en su margen derecho son navíos redondeados, sin velamen ni espolón de proa. El timón lo conforman 2 remos, uno a cada lado de la popa. La propulsión es a fuerza de remo y se ignora si los remeros y la marinería eran esclavos o libres. Sin duda los buques hititas no serian muy diferentes. Su situación de trabajo era en bancales bajo la cubierta en la que iba la tropa de infantería, armados de cascos, jabalinas y escudos redondos. Observese que la generalidad de la tropa es, aparentemente idéntica y barbada, excepto 2 personajes (en cada barco) imberbes y portadores de cascos más alargados que protegen sus hombros y espaldas. Podria conjeturarse que son jefes, que visten corazas de placas, similares a la de la figura $n .^{\circ} 36$ (que

3.4 Tablilla acádica de los "archivos de Ugarit», descubierta en la llamada "casa de Rapanu" en el barrio residencial. Vid. nota anterior, pág. 14.

35 Vid. bibliografía no exhaustiva. 


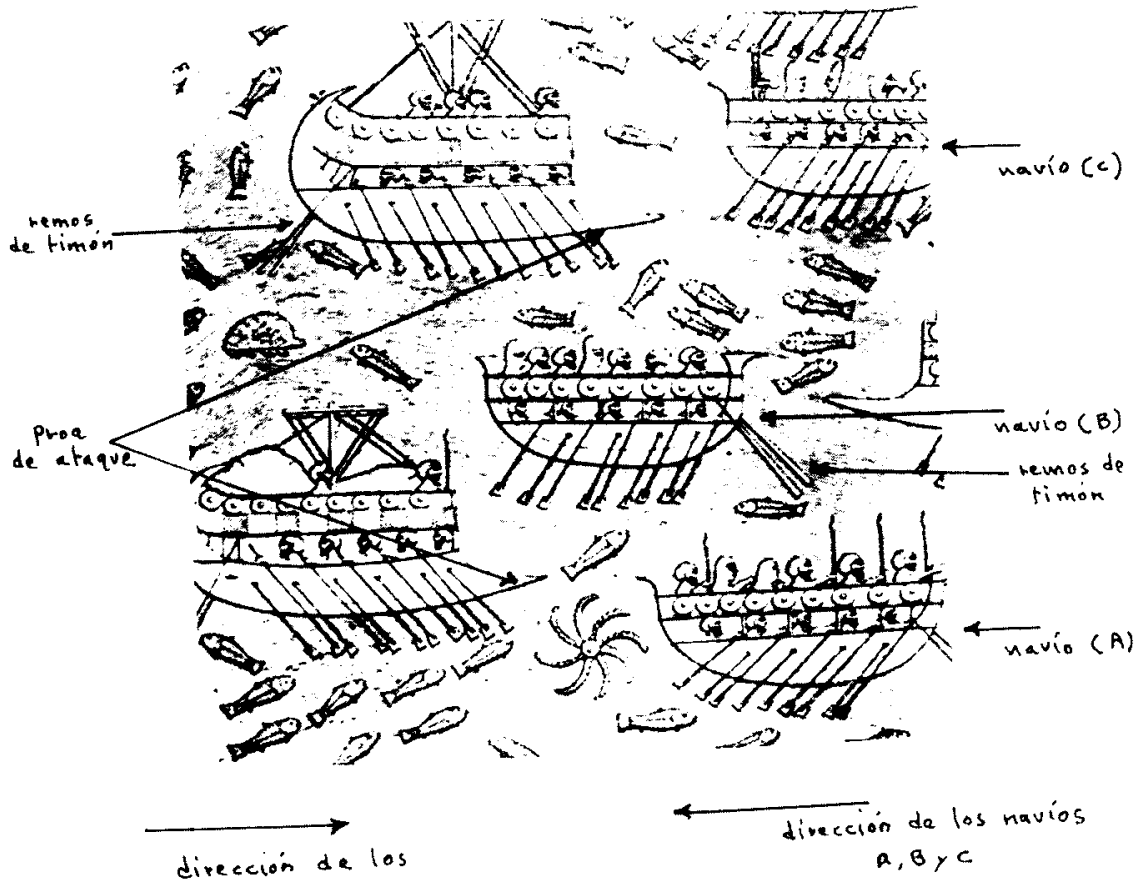

navios DYE

representa un barco arcaico de factura griega. Figura $\left.n .^{\circ} 58\right)$. Sin duda hay razones que nos hacen creer que los buques portaban distinta tropa, especializada podríamos decir, si nos guiamos por las diferencias que portan las mismas. En el navio (A) la tropa lleva enhiestas las lanzas o jabalinas, mientras en el (B) y en el (C) carecen de ellas. Puede que sean portadores de mazas, espadas o arcos y flechas, pero nada nos lo indica (independientemente de las salvedades que significan haber lomado un modelo fenicio ante la carencia de modelos originales hititas)

Parece que se trata de un enfrentamiento naval entre distintos tipos de buques, radicalmente diferentes, pues mientras unos carecen de mástiles $y$, por tanto, de velamen, los otros lo llevan, además de una afilada proa de ataque (navios $D$ y $E$ ).

Con toda claridad se ve que los navios sin velamen, como si fuesen grandes barcazas impulsadas por remos, llevan la dirección derechaizquierda, a juzgar por los 2 remos que hacen la función de timón a popa; 


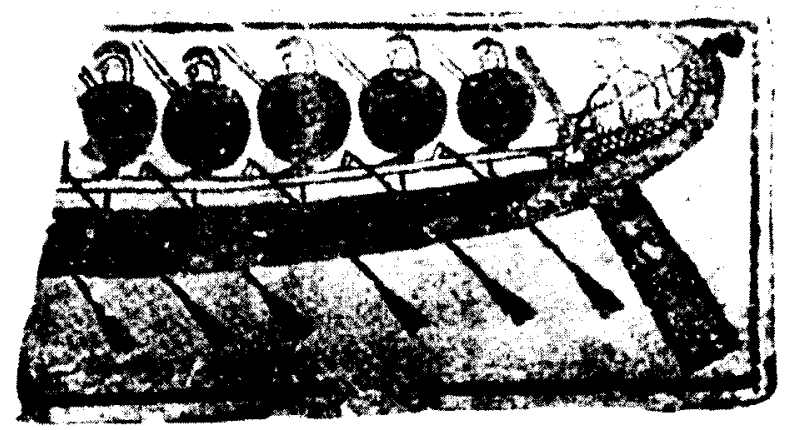

Figura 58

mientras que los buques portadores de mástil, único y central, y velamen, se dirigen a su encuentro; es decir de izquierda a derecha. No son buques acompañantes o protectores, muy al contrario parecen navios enemigos. Confirma nuestra opinión la dirección de los remos. Cada buque ejerce con ellos un movimiento de impulsión y avance. De tal suerte que los remos se llevan hacia delante en el aire, para hundirlos despues en el agua y, una vez dentro, impulsar con fuerza las paletas que hagan avanzar a la nave al encuentro del enemigo. Con toda lógica los remeros dan la espalda a la dirección de avance de la nave.

Pero hay que observar dos detalles para los que no encontramos explicación: Los navios ( $D$ y E); es decir, los de velamen y proa de ataque, situados a la izquierda del lector, llevan sus hombres de cubierta mirando a sus contrarios. El navio (A) da la espalda al (D) que, por otro lado, a pesar de aparentar un buque de guerra, en su cubierta no lleva otra cosa que 2 montones de carga y 2 marineros, uno de ellos armado con una lanza. El navio (B), excepto uno de sus marineros, da también la espalda toda la tropa, mientras que en el (C), hay mezcla de posiciones. Qué significado simbólico pueda tener, si es que tiene alguno, o simplemente se trata del capricho del dibujante, nunca lo sabremos.

Confirma todo lo anterior la figura $n .^{\circ} 59$, modelo de barco hitita con mástil y velamen, a la vez que remos, como fuerza impelente coadyuvante del viento. $Y$ modelos de navios sin mastil y, por tanto, sin el impulso del viento o brisa marina sobre las velas son, el barco cicládico de la figura $n .^{\circ} 60$.

Un modelo de barco, aparentemente fluvial, ligero (por su estructura) sumerio, es el correspondiente a la figura $n .^{\circ} 61$, donde se aprecia la colocación central de la carga, mientras el timonel, a popa, dirige el timón, y un solo remero impulsa el navío a proa. Esta figura, junto a los $n .^{\circ} 47,50$ 


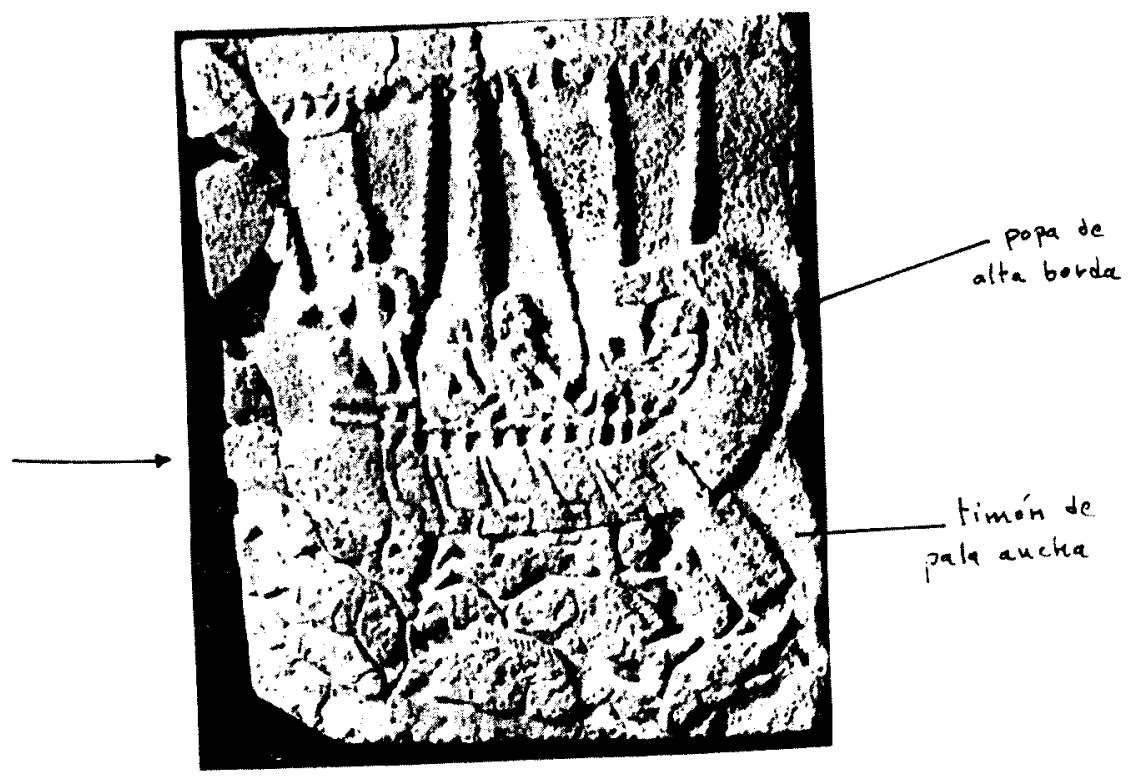

Figura 59

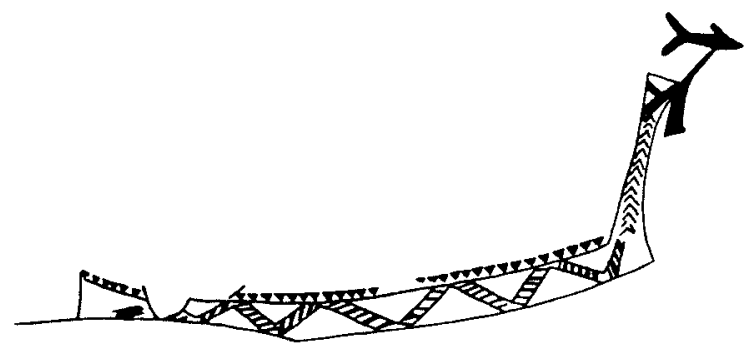

Figura 60

y 53 , corresponde a los paneles broncineos de las puertas de Balawat, decoradas por orden de Shalmanasar III (858/824 a.C.)

Temporalmente, y al igual que en tierra, las campañas bélicas se veían limitadas, por la bonanza del tiempo y, sobre todán. No hay más que ver la
mentos más oportunos para dirigir tales campañas.
carta que envia el rey de Tiro al de Ugarit ${ }^{36}$ notificándole el naufragio, entre

36 CunCHILlos, JL. "Textes Ougaritiques, II". Littératures anciennes du Proche-Orient 14. París, 1989 (Págs. 349/357). 
los meses de diciembre y marzo, dadas las lluvias torrenciales y tormentas de esa región, de parte de la flota que transportaba desde Egipto trigo para simiente, dado que la flota ugarítica era frecuentemente arrendada para el transporte mercante de materias agrícolas, lingotes de productos metalúrgi$\cos$ y otras materias no menos utilizadas. Diversos pueblos surcaban las aguas del mediterráneo oriental y, sobre todo, el Egeo. Rutas bélicas y comerciales, todas estratégicas, se entrelazaban y la isla donde se asentaba Alashiya y la costa del levante con Ugarit, Kadesh y Biblos, sin olvidar Creta, fueron testigos de las incursiones marinas hititas. No podemos olvidar que el Imperio hitita reclamó como suya a Alashiya durante doscientos años (1400/1200 a.C.), hasta el punto de que sus documentos nos hablan de la batalla naval ganada por Shubiluliuma II a Alashiya en 1190 a.C., completándola con una incursión por tierra e imponiendo un tributo de mujeres, niños, plata y lingotes de cobre, asegurando así un flujo tributario y una extensión de sus fronteras exteriores con un fin definitivamente económico. Así puede explicarse que tras el equilibrio de poder conseguido en esta zona del mediterráneo entre los imperios hitita y egipcio a raiz de la batalla de Qadesh en 1285 a.C, a orillas del rio Orontes, se viese, poco tiempo después, muy amenazado por lo que los egipcios llamaron luego «pueblos del mar". Y, siguiendo los acontecimientos históricos comprobados, veremos cómo tras la derrota de estos pueblos por Ramses III en 1182 a.C., tanto en la batalla del Sinaí, como en el combate naval en un brazo del delta nilótico, muchos componentes de estos pueblos se fueron asentando en Palestina, como los «tjeker» en la costa de Haifa; los «danunas» en el valle del Jordán y los «peleset» en Ascalón y Gaza.

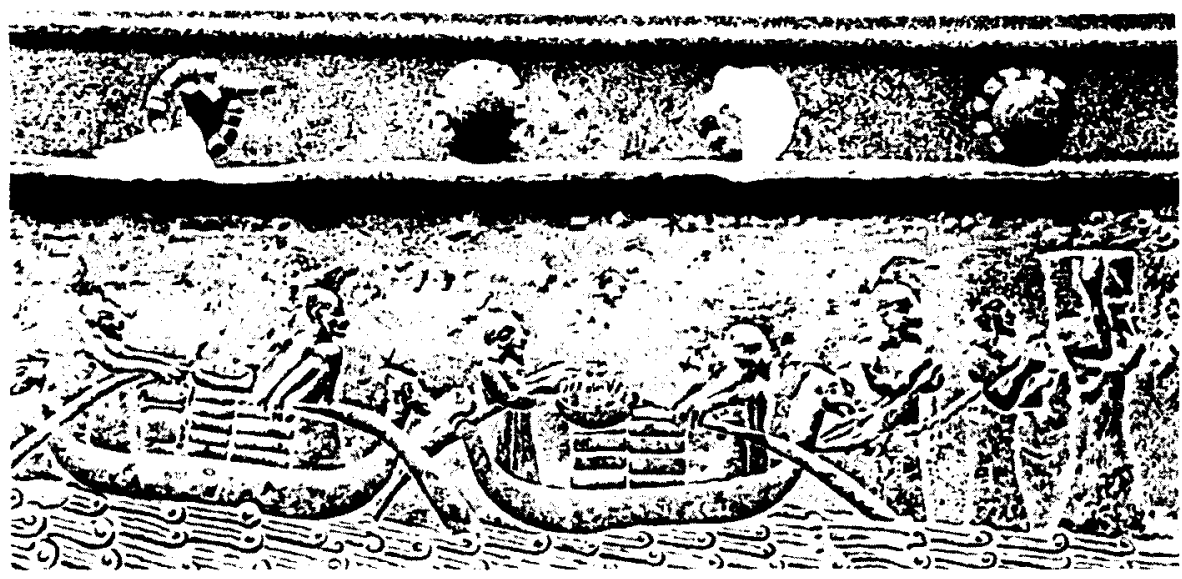

Figura 61 
Se destruyen imperios, entre ellos el hitita que quedan reflejados en la inscripción del templo de Medinet Habu en Egipto, cuando dice sobre aquellas migraciones no siempre pacíficas: "Nadie se oponía a ellos, desde Hattusa, Kode, Karkemish, Arzawa y Alashiya".

Lo cierto es que, independientemente de las ampulosidades egipcias, puede que la destrucción de algunos imperios, entre ellos el hitita tuviese varios frentes: Los gasgas que, desde tiempos inmemoriales fueron sus enemigos tradicionales y presionaron de manera permanente desde la franja costera anatólica del Mar Negro, las pestes y gastron altamente, los cas que sufrieron en varias ocasiones y que los diezriféricos vasallos, los levantamientos y sublevaciones de migraciones y, por último el gran incendio que destruyó la capital. Hattusas. Arzawa contra Tudhaliya IV, hacia ta la rebelión que encabezó el reino el 1250 a.C.

La figura $n .{ }^{\circ} 62$ corresponde a la maqueta de un barco velero, encontrada en una tumba de Beni Hasan, de la XII dinastía egipcia y que se encuentra actualmente en el Ashmoleam Museum de Oxford.

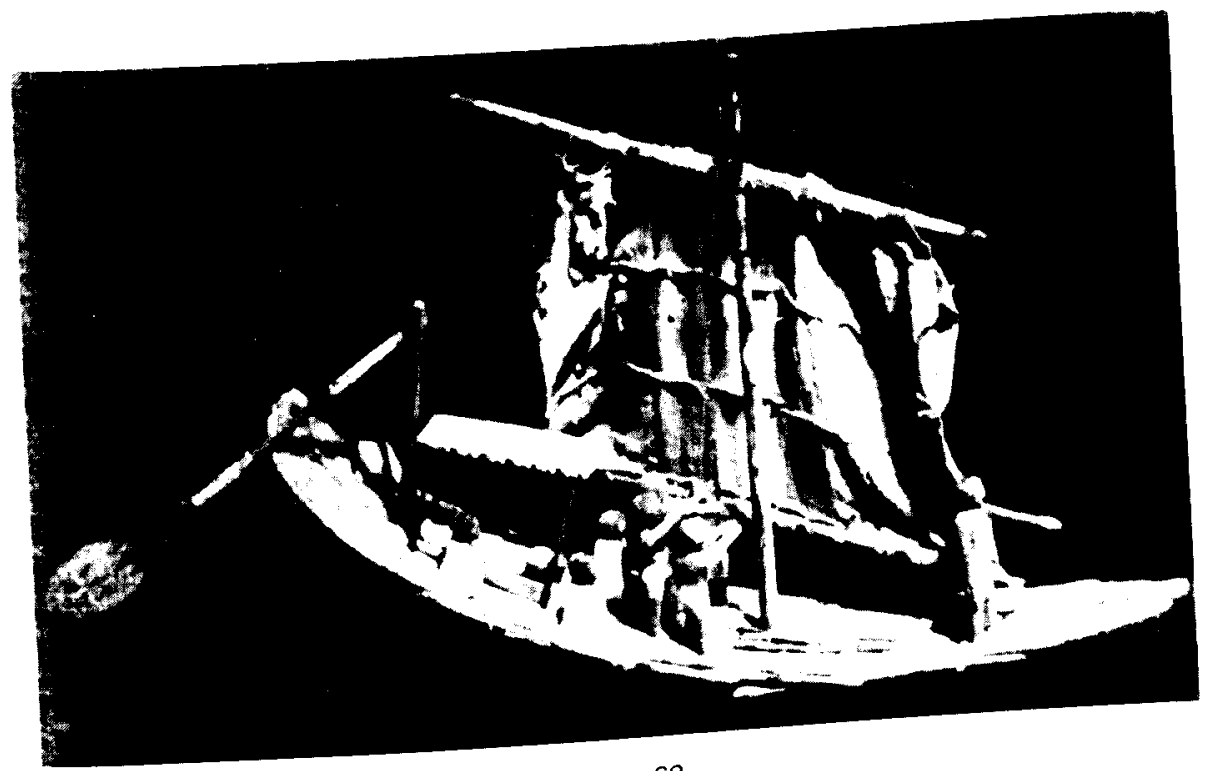

Figura 62 


\section{CONCLUSIONES}

Tratándose de un trabajo de acercamiento a las armas hititas, de cuyo conocimiento científico estamos harto huérfanos, sólo podemos acercarnos a pueblos, circunstancias y momentos históricos relacionados con otros pueblos de los que nos han quedado mejores y más datos. Dentro de la arqueología hitita no es, precisamente, amplio el conocimiento de sus armas, de tal suerte que hemos de suponer, dentro de un conocimiento más amplio de otros pueblos limítrofes, su armamento que es, en concreto, el tema de nuestro estudio. Nos conformamos con que otros estudiosos amplien estos datos de acercamiento a las armas puramente hititas que, sin duda, no eran muy diferentes a las de los pueblos con los que convivieron.

Cuchillos, espadas, lanzas, flechas, arcos, hachas, escudos, protecciones corporales a las que podemos darle el nombre que se nos ocurra, etc, sin duda eran materia conocida y utilizada por aquel pueblo que, si algo sin duda supo hacer, fue pionero en la utilización del carro ligero de guerra, como arma eficacísima en aquellos tiempos, así como la estrategia de su uso para ganar batallas. Pero eso no fue suficiente. Otros pueblos, los «del mar» los arrasaron. Sólo Ramsés III (es cierto que momentáneamente para la Historia), los retraso en su oleada de dominio. Vendrán otros tiempos, otros pueblos, que también dominarán Egipto. Hatti, hace tiempo que ya no existe. Pero ahi queda su historia. $Y$ la historia de sus armas es parte de su historia.

Sólo deseo que, estudiosos, mejor preparados que yo, amplíen el conocimiento hitita en su armamento, teniendo en cuenta que hay pueblos que dejan huellas indelebles en sus tumbas. No es el caso frecuente de Hatti.

\section{BIBLIOGRAFIA NO EXHAUSTIVA}

AldRED, C.: Los egipcios. Promociones y ediciones. Madrid, 1985.

ALONSO Y ROYANO, F.: Una pequeña aportación a la historia universal del derecho a través del comentario al "código" de Hattusas. B.I.C.A.O. n. ${ }^{\circ}$ 24/25. Págs. 59/66. Años 1986/87.

- El régimen matrimonial en el "código" de Hattusas. E.T.F. Serie II. N. ${ }^{\circ} 6$. Págs. 47/57.UNED. Madrid, 1996.

- La ciudad y el ciudadano en Egipto. E.T.F. Serie II. N. ${ }^{\circ}$ 10. Págs. 35/61. Historia Antigua. UNED. Madrid, 1997.

BaInes, J y MALEK, J.: Egipto. Edic. Folio. Barcelona, 1988.

Bandinelli, R.B. (dir.): Historia y civilización de los griegos. Tomo I. (F. Canciani). "La crisis de la cultura geométrica" Icaria/Bosch. Barcelona, 1982.

Bernabé, A. y Álvarez-Pedrosa, J.A.: Historia y leyes de los hititas. Akal Oriente. Madrid, 2000. BITTEL, K.: Los hititas. Aguilar. Madrid, 1976. 
Cassin, E./Bottéro, J./Vercoutter, J.: Die Altorientalischen Reiche 11. Das Ende 2. Fischer Bücherei, K.G. Frankfurt am Main. 1966.

Ceram, C.W.: El misterio de los hititas. Orbis. Barcelona, 1987.

CotTerell. A.: Origins of european civilization. The Rainbird Publishing Group Ltd. London, 1985.

Cunchillos, J.L. y Zamora, J.A.: Gramática ugarítica elemental. Edic.

CunChillos, J.L.: Visto desde Ugarit. Edic. Clasicas. Madridona, 1984.

EgGebrecht, A.: El antiguo Egipto. Plaza \& Janés. Bas. (3 tomos). Electa. Milán, 1989.

Donadoni Roveri, A.M.: Civilizacion de los la 2. ${ }^{a}$ mitad del s. Iv a.C.). Historia Antigua

Fernandez Uriel, P.: El Mundo Griegd de origenes hasta las invasiones de los pueblos

GarelLI, P.: El Próximo Oriente asiático (

GuRney, O.R.: The Hitites. E. Rev. Harmondswoerth. 1980. Ed. Destino. Barcelona, 1975.

M. Losiento de los frescos del Tasili. Ed 1976

Marti-Brugueras, M. M.: Los Hititas. Brugue ledit.): La ley más antigua (textos legales sumerios). Ed. Trotta. Madrid, 2000.

MOLINA, M. (edit.): La ley más antigua (textos legation. 1947.
SOMMER, F.: Hethiter und Hethitisch. Stuttgart,

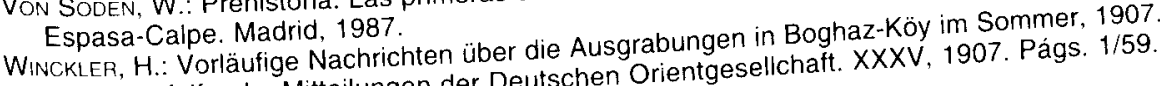
Die Tontafelfunde. Mitteilungen der Deutschen Orientgesellchaft. XXXV, 1907. Págs. 1/59.

Sobre los hititas se ha escrito tanto que es prácticamente imposible expresar nada nuevo. Quizás hacer sólo recopilaciones sobre temas puntuales, amén de las novedades filológicas en documentos que, sobre ellos, han llegado hasta nosotros.

* La bibliogratia que presenta esta obra es de consulta conveniente.

- La bibliografía presente en este volumen, en su mayor parte en lengua alemana, es lo suficienteno repetirla aquí; y es ahi donde debe consultarse.

\section{ABREVIATURAS UTILIZADAS}

B.I.C.A.O.: Boletin del llustre Colegio de Abogados de Oviedo.

C.A.B.: Centro Asociado "Bizkaia".

E.T.F.: Espacio, Tiempo y Forma. Revista de la Facultad de Geografía e Historia de la UNED.

M.A.A.: Museo Arqueológico de Ankara (Turquia).

M.E.C.: Museo Egipcio de El Cairo (Egipto).

UNED.: Universidad Nacional de Educación a Distancia.

-...-: Significa «idem" o el mismo autor. 